Int. J. Dev. Biol. 56: 519-534 (2012)

doi: $10.1387 / \mathrm{ijdb} .123502 \mathrm{gp}$

\title{
Hydractinia, a pioneering model for stem cell biology and reprogramming somatic cells to pluripotency
}

\author{
GÜNTER PLICKERT ${ }^{*, 1}$, URI FRANK² and WERNER A. MÜLLER ${ }^{3}$ \\ ${ }^{1}$ Biocenter Cologne, University of Cologne, Germany, ${ }^{2}$ School of Natural Sciences and Regenerative Medicine \\ Institute (REMEDI), National University of Ireland Galway, Ireland and \\ ${ }^{3}$ Centre for Organismal Studies, University of Heidelberg, Germany
}

\begin{abstract}
Hydractinia, a representative marine colonial hydroid, was the first organism in the history of biology in which migratory precursors of germ cells were described and termed "stem cells" (Weismann, 1883). These stem cells, now known as interstitial cells (i-cells), are thought to remain pluripotent throughout their life. Using animals depleted of their own stem cells and repopulated with allogeneic mutant donor stem cells, it was shown that Hydractinia i-cells differentiate into any cell type including epithelial cells and germ cells that express germ line markers such as Vasa, Piwi and Nanos. In Hydra, i-cells also provide germ cells and somatic cells with the exception of epithelial cells. The latter derive from two subpopulations of differentiated epithelial cells with self-renewal capacity. In Hydractinia, forced expression of the Oct4-like transcription factor, Polynem (PIn), in epithelial cells transforms them into stem cells that develop neoplasms. I-cells express the Wnt-receptor Frizzled and are Wnt responsive. Activation of Wnt signaling induces the production of numerous nematocytes (stinging cells) and nerve cells. In parallel, supernumerary tentacles develop. I-cells also express $M y c$ and Nanos. Their misexpression causes severe developmental defects. Hydractinia polyp buds arise from aggregating stem cells, in contrast to Hydra buds, which derive from evaginating epithelial cells. Wnt activation increases budding frequency and the emergence of ectopic head structures. The potential of stem cells to invade neighbors may have provided selection pressure for the evolution of allorecognition and histo-incompatibility. Hence, Hydractinia have now attained the position of a powerful model in stem cell research, axis formation and allorecognition.
\end{abstract}

KEY WORDS: iPSC, transdifferentiation, Wnt pathway, Nanos, Vasa, Piwi, Hydra, Hydractinia, Podocoryne

\section{Introduction to the Hydractinia model system}

\section{A historical survey on the significance of marine hydroids for cell and developmental biology}

From a historical perspective, marine colonial hydroids, having been out of the focus of mainstream biology for decades, deserve credit as they were the first organisms whose cellular inventory had led scientists of the 19th century to coin several basic concepts and terms in biology, namely 'stem cells' ("Stammzellen"), 'primordial germ cells' ("Urkeimzellen"), and 'germ line' ("Keimbahn"). The first publication known to us documenting the use of these terms is a comprehensive monograph on the origin of germ cells in 38 species of marine hydroids, published by August Weismann in 1883 and illustrated with many copper-plate engravings showing migratory precursors of germ cells. The term 'stem cells' is found in the chapter dealing with Hydractinia echinata and was used by Weismann to point to putative migratory sperm progenitors. The term 'primordial germ cells' appears several times in chapters dealing with Hydractinia, Podocoryne and Eudendrium and in the legends of many figures. The terms 'germ line' and 'germ plasm' ("Keimplasma") was coined by Weismann in later essays (Weismann, 1889, 1893) with reference to those studies on hydroids. ("Germ plasm" in the theoretical concept of Weismann is the complement of genetic information thought by him to be allocated only to the germ line.)

After a long lag period, members of the genus Hydractinia eventually became model organisms in studies on allorecognition and migratory stem cells, whereas Podocoryne carnea (synonymous Hydractinia carnea, Schuchert, 2011) remained a pre-genetic

Abbreviations used in this paper: i-cell, interstitial stem cell; Pln, polynem.

*Address correspondence to: Guenter Plickert. Biocenter Cologne, University of Cologne, Germany. e-mail: g.plickert@ uni-koeln.de

Final, author-corrected PDF published online: 5 June 2012

ISSN: Online 1696-3547, Print 0214-6282

(C) 2012 UBC Press

Printed in Spain 
model organism for regeneration through transdifferentiation and dedifferentiation of somatic cells to multipotency. As allorecognition in Hydractinia has recently been reviewed (Rosengarten and Nicotra, 2011) this aspect will be addressed in the following sections only in respect to stem cells behaviour. Additionally, in Hydractinia, classical and recent topics of general developmental biology have been under investigation such as the role of the canonical Wnt-signaling system in the establishment of the body axis, pattern formation and pattern control in embryogenesis and postembryonic development, organizing centers and induction of structures. Prerequisite for many of these studies was the successful induction of metamorphosis of the planula larvae into primary polyps - the founder of new colonies - by defined factors and the possibility to perform genetic crosses and to establish inbred lines over several generations in tolerable times.

Another favourable feature that both Hydractinia and Podocoryne offer to the experimentalist and shared with most members of the Cnidaria is the easy way in which animals can be cloned using explants (Frank et al., 2001). Recent progress in the successful novel model hydroid Clytia hemisphaerica will only occasionally be mentioned but not comprehensively reviewed in this context (for references see Houliston et al., 2010; Technau and Steele, 2011). Since the species preferentially addressed here, i.e. $\mathrm{Hy}$ dractinia, is not familiar to the majority of biologists, a sketch of its morphology, life cycle and some basic experimental results will prepare expositions on stem cells and cellular reprogramming.

\section{The divergent life cycle of Hydractinia among Hydrozoans}

Among cnidarians, medusozoans (hydrozoans, cubozoans and scyphozoans) differ from anthozoans (corals and sea anemones) by a complex metagenetic life cycle. By definition, in a metagenetic life cycle a first juvenile life stage, called polyp, alternates with a second, asexually produced stage, known as medusa or jellyfish. This second stage is the adult, sexually reproducing stage. By producing gametes the medusa gives rise to the larval planula, which metamorphoses into a polyp that can stay solitary or form a colony (Collins et al., 2006). However, some species of the

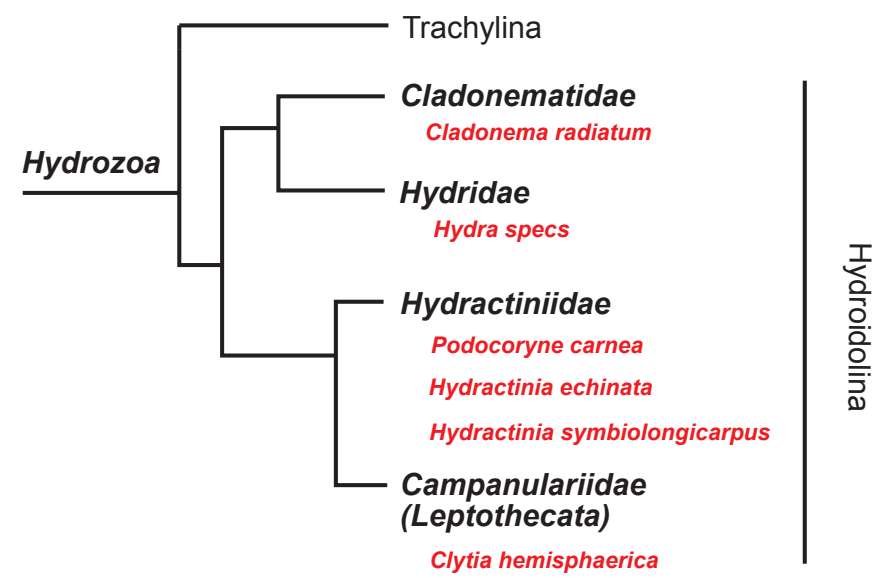

Fig. 1. Phylogenetic classification of the hydroids mentioned in this article laccording to: The Hydrozoa Directory, P. Schuchert, 2012, www. ville-ge.ch/mhng/hydrozoa/hydrozoa-directory.htm). While the families of Cladonematidae and Hydridae belong to the suborder Capitata, all other hydroids belong to Filifera. Exclusively Clytia is a thecate hydroid (Leptothecata); the other species belong to the order Anthothecata. medusozoans have secondarily lost the medusa stage and the polyp produces gametes directly (as do anthozoans). This also applies to the well-known model organism Hydra. Having lost the medusa and the planula stage, the solitary freshwater polyp Hydra displays a highly derived life cycle. The marine colonial genera Hydractinia and Podocoryne are medusozoans, that also belong to the Hydrozoa class, anthoathecata order. However, the family of Hydractiniidae with Hydractinia and Podocoryne and the genus Hydra group in different suborders (for phylogeny see Fig. 1).

In nature, colonies of Hydractinia and Podocoryne are mostly found in on shells inhabited by hermit crabs. They share many basic features in the architecture of the colony but differ in one important aspect: Podocoryne, of which the best-studied species is $P$. carnea, displays a full metagenetic life cycle including freeliving medusae (jellyfish). Hydractinia, in North-European seas represented by $H$. echinata, in the USA by the sibling species $H$. symbiolongicarpus, differs from Podocoryne in this aspect as its medusa stages are morphologically reduced and remain attached to the polyp, actually serving as gonads and called gonophores (Fig. $2)$. In both genera, gametes are released into the water column.

Fertilized eggs develop into a planula larva. Planulae metamorphose to primary polyps, the founders of new colonies consisting of clonal, interconnected secondary polyps. Their interconnection is achieved through a gastro-vascular system, called stolons. These are blood vessel-like tubes which cover the substratum by extending and branching, and bud new polyps. The stolons are enclosed by a protein-chitin exoskeleton that is secreted by the epidermis and in traditional treatises called perisarc or periderm. In Hydractinia and Podocoryne the perisarc does not enclose the polyps, similar to other athecate hydroids. In mature colonies a fraction of the secondary polyps differentiates into specialized polyps on which medusae or gonophores develop.

An additional difference between the two genera is the structure of the stolonal tissue. In maturing Hydractinia the stolons form a compact mat or plate, composed of an epidermal epithelial bilayer enclosing the gastrodermal network of tubes (see Fig. 5A), whereas Podocoryne maintains runner-type stolons throughout life. Embryonic development is different as well: Podocoryne gastrulates by polar ingression and the morula/blastula creates a blastocoel. Hydractinia, instead, develops a solid sterroblastula and generates the endoderm through apolar cell reorganization. Thus, from an evolutionary standpoint Hydractinia is more derived than Podocoryne; from a practical standpoint the reduction of the free-living sexual generation to gonads is an important advantage since it is not necessary to rear tiny and delicate medusae to sexual maturity. In Hydractinia colonies, the sexes are separate, stable and probably genetically determined (Hauenschild, 1954; Müller, 1964). Male and female gonads release their gametes in the morning, induced by the onset of light. Thus, fertilized eggs can be harvested almost daily. They develop to planula larvae within two-three days.

\section{The life cycle requires external cues to proceed to completion}

Planula larvae do not enter metamorphosis spontaneously. Instead, they require external cues indicating them an appropriate substrate on which to settle as do the larvae of many other marine sessile organisms. Hydractinia played a pioneering role in identification of such cues. Its planulae were the first marine larvae of which metamorphosis was shown to be induced by 
A
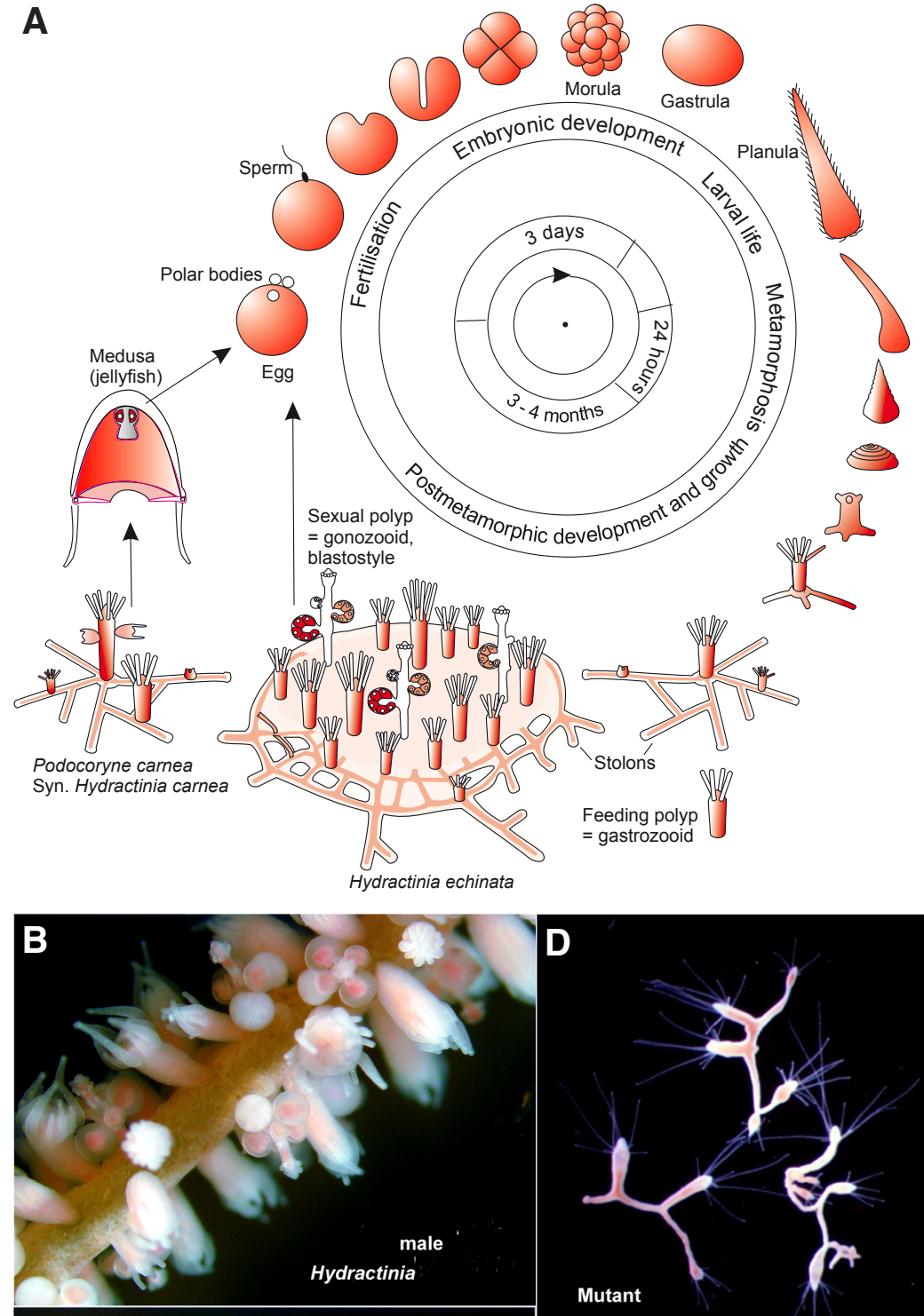

D
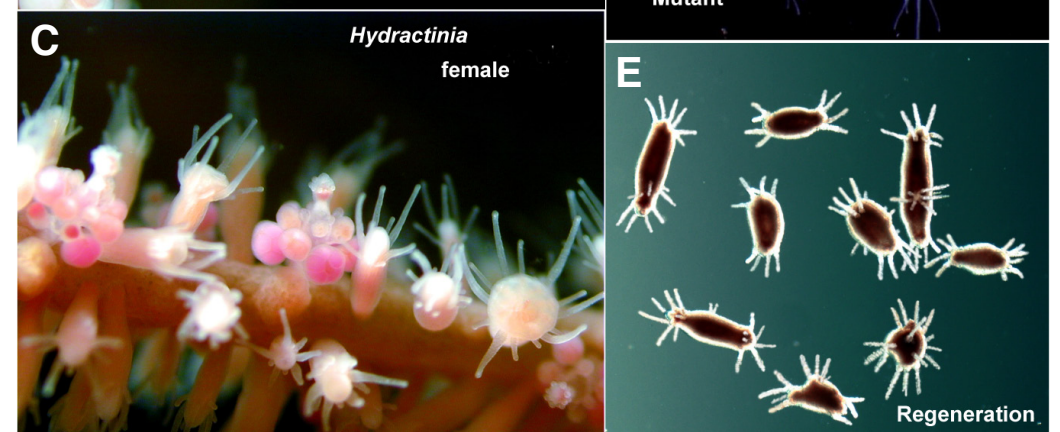

Fig. 2. Hydractinia and Podocoryne: life cycle and experimentally induced multihead formation. (A) Life cycle of Hydractinia echinata and of Podocoryne carnea. Part of the figure concerning Hydractinia is from Müller: Entwicklungsbiologie, 5th ed., Springer Berlin Heidelberg New York, 2009, supplemented here by the part concerning Podocoryne. (B,C) Hydractinia echinata; male and female colony. Photos gift to WM by Yuki Katsukura. (D) Multiheaded polyps from a mutant clone. (E) Bipolar head regeneration in pieces of the body column excised from gastrozooid. This can occur spontaneously but the frequency is strongly increased if the pieces are excised from colonies treated with azakenpaullone, an inhibitor of GSK3; this treatment causes activation of the Wnt pathway. After Müller et al., 2007, Duffy et al., 2011, hitherto unpublished photo by WM. bacteria (reviewed by Müller and Leitz, 2002). This dependence on environmental bacterial films has since been verified in many other marine organisms including oysters, barnacles and several other cnidarians (e.g. the scyphozoan Cassiopea andromeda and the anthozoan Acropora millepora, (Neumann, 1979; Fitt et al., 1990). A compound inducing metamorphosis in Acropora millepora was isolated from a Pseudoalteromonas bacterium and identified as tetrabromopyrrole (Tebben et al., 2011).

The presence of external cues is perceived by neurosensory cells at the anterior, aboral pole of the larva (anterior with respect to the positive phototactic movement of the crawling larva). Agents capable of depolarizing and thus of stimulating neurosensory cells can conveniently be used to induce metamorphosis at any time (reviewed by Frank et al., 2001). Furthermore, interference with signal transducing systems by applying activators of PKC such as tumor-promoting phorbol esters can stimulate larvae to enter metamorphosis as well (Müller, 1985). Upon stimulation, neurosensory cells release diffusible neuropeptides of the GLWamide class as hormones to start and synchronize the internal reorganization necessary for the transformation of the larva into a polyp (Schwoerer-Boehnig et al., 1990; Leitz et al., 1994; Gajewski et al., 1996; Schmich et al., 1998; Plickert et al., 2003). Metamorphosis is associated with the release of low molecular inhibitory, methyl-donating substances, into the external medium (Berking, 1987; 1988), and by apoptosis-mediated elimination of larval neurons and nematocytes (Seipp et al., 2001, 2010). Anatomical and ultrastructural details of metamorphosis have been described previously (Van de Vyver, 1964; Weis and Buss, 1987; Martin and Archer 1986, 1997; Martin, 2000). The postmetamorphic development and structure of a colony was described by Müller (1964). For a more detailed review of Hydractina's life cycle and rearing conditions in the lab see Frank et al., 2001.

\section{Organization and regulation of the adult colony}

\section{Compartments of the colony, spacing patterns and division of labor}

Colonies of Hydractinia and Podocoryne consist of two main compartments that differ in morphology, behaviour and cellular composition: the stolons and the polyps. In the network of stolons, spacing of branches is controlled by inhibitory signals emanated by the distal stolon tip, a motile organ fulfilling pathfinding functions similar to the terminal cell of growing blood vessels (Fig. 3). The inhibitory field extends from the distal tip about $400 \mu \mathrm{m}$ in proximal direction with declining intensity (Müller and Plickert, 1982).

On the other hand, the stolon tip is also source of a signal molecule termed stolon-inducing factor (SIF: Lange et al., 1989, Lange and Müller, 1991). When growing to proximity to the flank of another stolon, secreted SIF induces the formation of a second, laterally growing tip (Fig. 3 C,D). This induction implies inducing stationary epithelial cells to a cohort able to move in a coordinated pulsating fashion (movie Müller, 1996), and it implies the 
dissolution of the chitinous envelope of the encountered stolon. A chitinase cloned from Hydractinia may be involved in this process (Mali et al., 2004). The inducing and the induced tip attract each other, a prerequisite for anastomosis formation (Müller etal., 1987), because tip tissue is the only epidermal tissue that can fuse with other epidermal tissue. However, fusion (Fig. 3 D-1) depends on both tips sharing the same histocompatibility alleles. If applied to the growing medium at supra-natural concentration, SIF causes complete transformation of polyps into stolons (Lange and Müller,
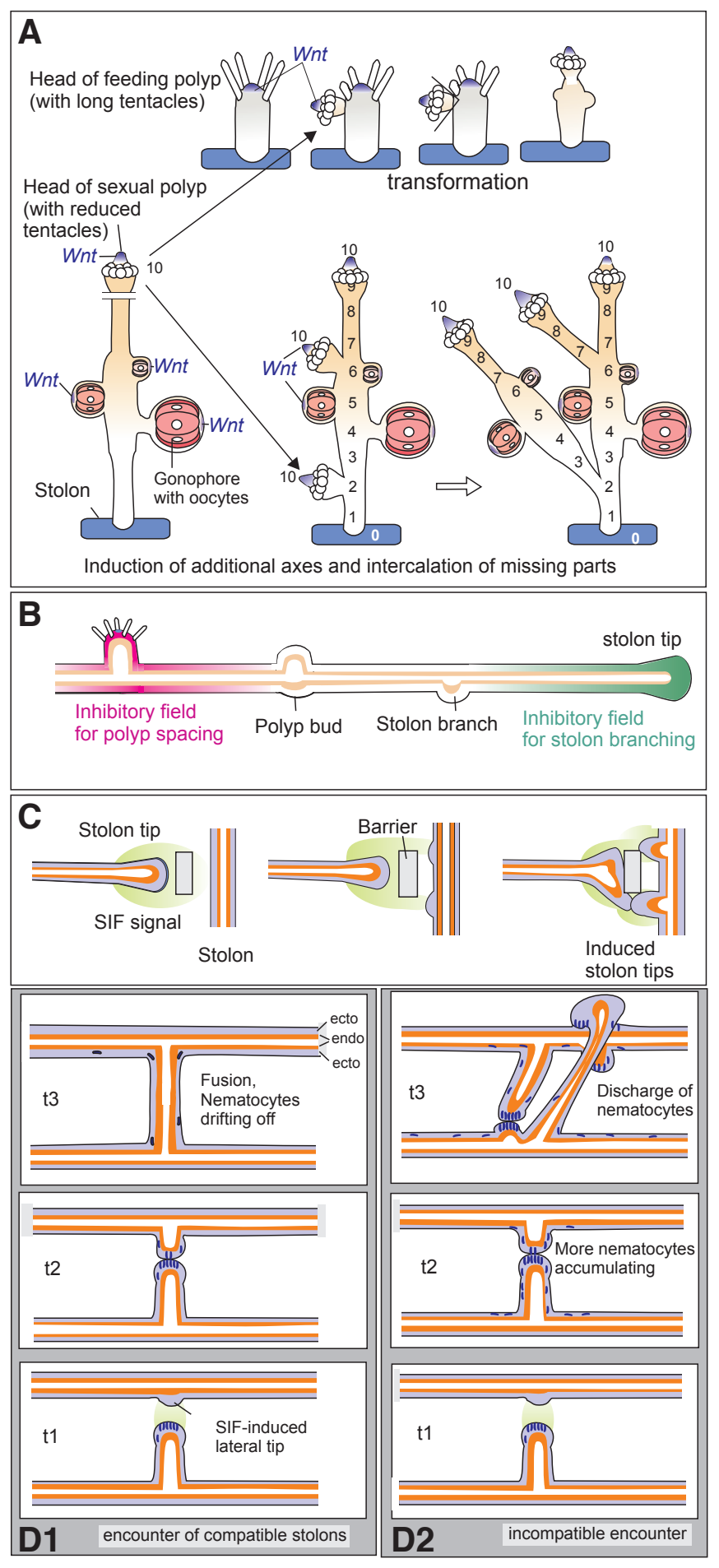

1991; Müller et al., 2004b).

Like spacing of stolons, spacing of polyps is controlled by lateral inhibition (Fig. 3B) characterized by similar system properties as in the colonial hydroid Eirene viridula (Plickert et al., 1986). In colonies of Hydractinia, spacing distances can be reduced, and budding frequencies increased, by exogenous retinoic acid (Müller, 1984). Stimulation of the Wnt-pathway has similar and even more dramatic effects (Müller et al., 2007) presumably, in part, by promoting stem cell proliferation.

Similar to the zooids of siphonophores, the polymorphic polyps of Hydractiniidae are textbook examples for the evolution of division of labor among individuals leading to supra-individual organisms (Müller, 1964). The polyps of the colony, though genetically members of a clone, exhibit division of labor by differentiating several morphological and functional subtypes: these are at least four in Hydractinia (gastrozooids, gonozooids, dactylozooids, tentaculozooids; Müller, 1964) and two in Podocoryne (gastrozooids, gonozooids; Boelsterli, 1977).

\section{Genetic markers of colony development}

Cnidarian genomes encode more homologues to vertebrate genes than the ecdysozoan model organisms Caenorhabditis elegans and Drosophila (Kortschak et al., 2004; Soza-Ried et al., 2010; Technau and Steele, 2011). In an EST database, Soza-Ried et al., (2010) found $>6000$ transcripts from genes that Hydractinia shares with vertebrates. This finding is strongly supported by further RNA-sequencing (unpubl.) and a draft genome assembly of Hydractinia echinata (work in progress), showing conserved gene inventory of all major signaling pathways used in animal developmental control. It is beyond the scope of this review to provide a comprehensive analysis of the Hydractinia genome and transcriptome. Some genes of significance in the present context are mentioned in the following sections (for comparison with other cnidarian model organisms see Chapman et al., 2010; Technau and Steele, 2011; Steele, 2012).

Thus far, only few regulatory genes have been implicated in colony development. Among them is Cnox-2, a gene of the Gsx/paraHox class, analyzed in H. symbiolongicarpus. Cnox-2 is expressed in epithelia of distal stolon tips, in polyp bud rudiments and in the basal body column of fully developed polyps (Cartwright et al., 2006). Cnox2-Pc, a Podocoryne homologue

Fig. 3. Classic experimental morphology in Hydractinia. (A) The head of a polyp, here represented by the head of a gonozooid, is an organizing center with inductive power. It can cause the transformation of a growing gastrozooid into a gonozooid, and it evokes the development of secondary axes the structure of which is governed by the rules of intercalation. Structures missing between inducing and responding tissues are inserted. Numbers indicate fictional positional values (after Müller, 1964, 1982). (B) Mechanisms of spacing by lateral inhibition. Spacing of stolon branches is controlled by inhibitory signals produced at the stolon tip and spreading in the tissue in proximal direction forming a gradient. A subthreshold strength of inhibition allows formation of a lateral tip and hence of a branch (after Müller and Plickert, 1982). Likewise, spacing of polyps is accomplished by lateral inhibition emanating from existing polyps (after Müller, 1984). (C) The advancing stolon tip emits SIF, a stolon- inducing factor that induces another tip(s) in the flank of an approached stolon. Inducing and induced tips attract each other circumventing a barrier placed between inducer and recipients (after Müller et al., 1987). (D). Outcome of encounters between isogeneic stolons (D-1) and between allogeneic, incompatible encounters (D-2)(after Müller et al., 1987). 
(Masuda-Nakagawa et al., 2000; Yanze et al., 2001) belongs to the orphan family Cnox-A (Chiori et al., 2009; Quiquand et al., 2009). It is expressed at the anterior pole of the larva, the oral pole of polyps, in buds, and the gastrodermal canals of the medusae (Masuda-Nakagawa et al., 2000). In contrast to their function in arthropods and vertebrates to specify segment identities, Hox-and paraHox-related genes in Cnidaria appear not to define sequential patterns of territories and conferring different identities to them (Yanze et al., 2001; Cartwright et al., 2006). Nevertheless, Hox and paraHox-related genes of Cnidaria are expressed at distinct narrow or large territories and at distinct time periods (Gauchat et al., 2000; Finnerty et al., 2004). They control differentiation as shown in a functional study on the essential role of Cnox-2 for the specification of neuronal fate in Hydra(Milijkovic-Licina et al., 2007).

Many genes for signaling molecules and transcription factors, which had previously been viewed as vertebrate-specific, are found with similar functions in Cnidaria. For instance, the endodermal canals in the medusae of Podocoryne carnea express, besides members of the BMP family (Reber-Müller et al., 2006), homologues of vascular endothelial growth factor and receptor, VEGF and VEGFR (Seipel et al., 2004a). Since stolons share many functional features with blood vessels, it would be interesting to examine stolons for the presence of angiogenic factors too.

\section{Axial patterning in the developing larva}

\section{Oocyte polarity, establishment of the body axis}

The origin of the primary body axis in the Cnidaria has for long been source of incorrect illustrations. Having in mind the situation in the classic textbook paradigm displayed, for instance, by sea urchin embryos, authors of older treatises (e.g. Tardent, 1978) have assigned the pole of gastrulation to that pole of the embryo, which, in classical terminology, is defined as vegetal pole. Traditionally, the animal pole of the egg is defined as the pole where in meiosis the polar bodies are given off. In sea urchins and other Deuterostomia, gastrulation occurs at the opposite pole. By contrast, in those cnidarians such as Nematostella vectensis or Podocoryne carnea where gastrulation happens in form of classical invagination (Martindale and Hejnol, 2009) or polar ingression, respectively, it is the pole marked by polar bodies where gastrulation commences.

In Podocoryne, gastrulation is restricted to the 'animal' $20 \%$ of the blastula (Momose and Schmid, 2006), whereas in Hydractinia endoderm formation appears not to be confined to one pole but occurs instead as rearrangement and subsequent epithelial organization of the cells in the morula. Nevertheless, the basic polar relationship is maintained also in Hydractinia. The pole marked by the polar bodies is the only site the sperm can enter the egg (Freeman, 1987) and this - in terms of classic nomenclature "animal" - pole is the site where the first furrow starts, the posterior pole of the larva arises and eventually the mouth of the primary polyp is formed in metamorphosis (Fig. 2A). Thus, the posterior pole of the larva and oral pole of the polyp correspond to the pole where - following the release of the oocytes in spawning - the polar bodies had been extruded. We therefore propose to abandon the usage of 'animal' and 'vegetal' poles in cnidarian embryos, and use 'oral' and 'aboral' instead.

An organizing center and covert prepatterns in the planula

Transplantation studies have shown that the posterior pole of the larva is an organizing center (Stumpf et al., 2010), as is the oral pole of polyps, being able to induce a secondary axis (see also Shimizu in this issue). This is reminiscent of cells around the blastopore in Deuterostomia, namely the Spemann organizer in amphibians and the micromeres in sea urchin embryos. Internally the larva contains a covert prepattern of the post-metamorphic adult pattern. This is visualized by the spatio-temporal pattern by which S-phase activity declines in mature planulae. Cell cycle arrest appears first in cells localized at the posterior and subsequently at the anterior pole of the elongating embryo (Kroiher, 2000; Kroiher et al., 1990; Plickert et al., 1988). When induced to metamorphose with neuropeptides, posterior halves of larvae give rise to heads only, anterior halves to stolons. The overt pattern of the polyp is generated under the influence of a covert antero-posterior polarity in the larva (Schwoerer-Böhning et al., 1990). However, this pattern is not irreversibly fixed. It can profoundly be altered by manipulating the canonical Wnt pathway, the center of which resides in the organizer region of the developing planula, i.e. in the terminal region of the developing larva tail (Fig. 4), and its derivative, the oral pole of the polyp (Stumpf et al., 2010; Plickert et al., 2006; Duffy et al., 2010). This is explained in more detail in the following section.

\section{Activation of the Wnt pathway leads to oralization in Hydractinia}

\section{Role of the canonical Wnt-signaling pathway in embryonic and larval stages}

Surprisingly, although in Deuterostomia and Cnidaria the primary embryonic polarity seems to be inverted (Martindale and Hejnol, 2009), in both groups the primary body axis is formed under the control of the canonical Wnt-signaling pathway. Basic constituents of the pathway are found as maternal transcripts in the oocyte, namely Wnt-3a, $\beta$-catenin, Frizzled and Tcf/Lef (Fig. 4). Wnt and Tcf transcripts are deposited in the oocyte and early embryo at the oral pole (Plickert et al., 2006). In Hydractinia, and likewise in the thecate hydrozoan Clytia (Momose et al., 2008) and the anthozoan Nematostella (Fritzenwanker et al., 2007), this pole is the pole marked by the polar bodies, whereas in sea urchin embryos the transcripts are located at the opposite pole. Common denominator is that $\beta$-catenin stabilization co-localizes with cleavage initiation and gastrulation.

The directing role of the Wnt-pathway in the establishment of the primary body axis is documented by experimental interference. Stimulation of the pathway in Hydractinia during gastrulation by inhibiting GSK3 with paullones or $\mathrm{Li}^{+}$upregulates the expression of Wnt3, Tcf and Brachyury and renders them ubiquitous. Subsequently, it transforms the anterior pole of the larva into a second, ectopic posterior pole. Following metamorphosis, these larvae give rise to double-headed polyps (Fig. 4), which frequently lack aboral structures, i.e. stolons (Plickert et al., 2006). Similarly, in metamorphosis, paullones transform the animal into a floating head. Rescue experiments in which paullone treatment is accompanied by Wnt or Tcf RNAi result in normal metamorphosis (Duffy et al., 2010). Finally, activation of Wnt downstream targets in regenerating animals also results in oralization of the polyps. Knocking down Tcfor Wnt3 by RNAi inhibits head regeneration. In summary, Wnt signaling promotes head formation but represses the formation of stolons, whereas down regulation of Wnt promotes stolons and represses head formation (Duffy et al., 2010).

Brachyury (Duffy et al., 2010; Stumpf et al., 2010) and Nanos 
(Kanska and Frank, 2011) are also expressed at this pole in $\mathrm{Hy}$ dractinia embryos and in Podocoryne and Nematostella larvae (Torras et al., 2004, 2005; Extavour et al., 2005). Thus, if Nanos is chosen as point of reference, the posterior pole of the larva and, hence, the oral pole of the polyp, correspond to the posterior pole in Drosophila.

Role of the Wnt-pathway in post-metamorphic development Many parallels exist between Hydractinia and Hydra in polyp development and regeneration; differences are of minor significance. For instance, fully grown polyps of Hydractinia regenerate only oral, but not aboral structures following the rule of distal transformation, in parallel to limb buds in amphibians and arthropods (Müller et al., 1986). Stolon regeneration does occur if Wnt is inhibited (Duffy et al., 2010). Transplantation studies reveal ability in Hydractinia

\section{Hydractinia}
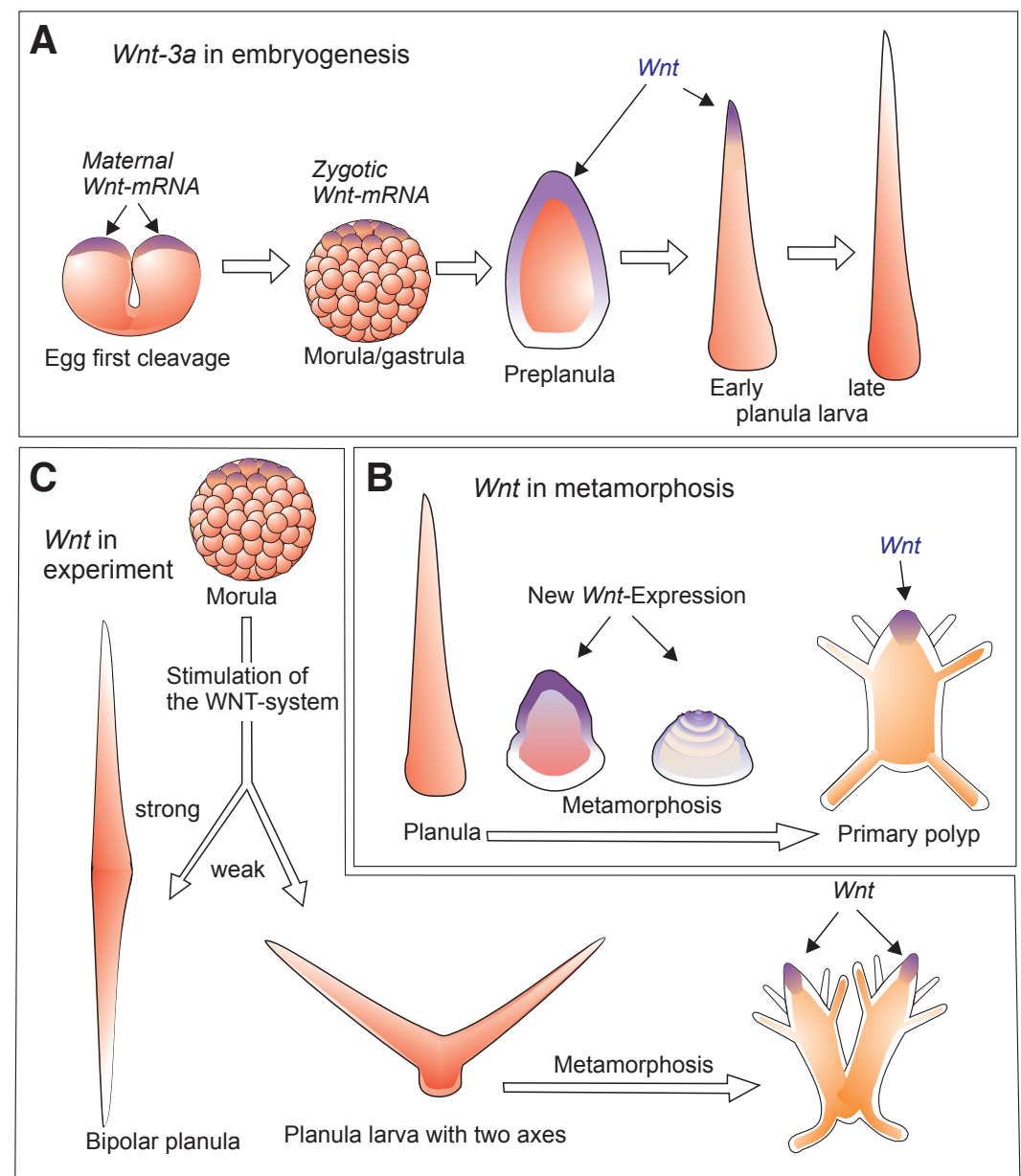

Fig. 4. Expression of Wnt3a during embryogenesis and metamorphosis of $\mathbf{H y}$ dractinia. (A) A local deposit of maternal Wnt mRNA directs commencing zygotic Wnt expression to both tissue layers of the posterior (pre-oral) preplanula. Embryonic Wnt expression is almost completely downregulated in the mature planula. (B) Wnt expression is re-activated in endoderm and subsequently also in ectoderm upon induction of metamorphosis. Broad expression in the oral metamorph spatially confines to the peri-oral tissues of epi- and gastrodermis in the primary polyp. (C) Experimental stimulation of Wnt signaling by Paullones (250 nM Alster- or Azakenpaullone for $17.5 \mathrm{~h}$ ): Developing planuale display multiple posterior axes that convert into oral polyp tissues. After Plickert et al., 2006. to sense changes of positional values and intercalate missing tructures. Some aspects of pattern formation and pattern control A promiation studies are summarized in Fig. 3 A-C.

A prominent feature Hydractinia shares with Hydra concerns for the first time in oral-most tissue of Hydra and, even more important, to contribute to the organizer quality of the head. Like in Hydra, blocking GSK3 generally leads to oralization. Polyps of Hydractinia treated with paullones (Müller et al., 2004b) transform to phenocopies of a multi-headed mutant (Fig. 2D) (Müller, 2002). Ectopic tentacles form over the body column in a similar way as Hydra does in response to paullones (Broun et al., 2005). Pieces of the body column excised from the gastric region of paullonetreated colonies regenerate a head not only at the oral but also at the aboral pole (Müller et al., 2007). Likewise, midgastric pieces treated after cutting formed heads at both ends (as in Fig. 2E; Duffy et al., 2010). Moreover, in some colonies of Hydractinia stimulation of the Wnt pathway evokes the emergence of giant polyp buds in the stolon mat. These giant buds encompass areas several hundred fold larger than normal buds; they subsequently separate to many, and often multi-headed, polyps (Müller et al., 2007).

In respect to the action of Wnt signaling in the polyp, Hydractinia and Hydra appear to be very similar. Concerning Wnt in embryonic development, however, Hydractinia and also Clytia appear to be different from Hydraas colonial hydroids direct primary axis formation by local deposits of Wnt mRNA in the egg (Plickert et al., 2006; Momose et al., 2008). In contrast, Hydra activates Wnt only in late embryogenesis when the axis has been already fixed (Fröbius et al., 2003).

\section{Stem cells in Hydrozoa}

\section{Identification and characterization of i-cells}

Most observations and investigations on stem cells in Cnidaria have been made in Hydra (reviewed by Bode, 1996; Bosch, 2007, 2009; Bosch et al., 2010; Watanabe et al., 2009; David 2012; Hobmayer 2012 in this issue) and in Hydractinia (Weismann, 1883; Hoffmann and Kroiher, 2001; Müller et al., 2004a; Teo et al., 2006; Rebscher et al., 2008; Künzel et al., 2010; Millane et al., 2011). The stem cells are also known as interstitial cells (i-cells) as they reside in interstitial spaces at the bases of the epithelia (Weismann, 1883). I-cells are only known from Hydrozoa, i.e. never found in anthozoans or other medusozoan classes (Frank et al., 2009).

However, in both genera, Hydra and Hydractinia, i-cells are not the only cells capable of proliferation. A subfraction of epithelial cells preserves the capacity to divide and contributes to the self-renewal of the potentially immortal animals. Dividing epithelial cells are regarded, at least in Hydra, as stem cells even though they are already differentiated. They have maintained the capacity to divide (Bode, 1996) and, 
they are capable of differentiation as they convert to head-specific and foot-specific cells (Bosch et al., 2010).

I-cells are migratory and, therefore, not confined to a stationary and permanent niche. Besides their whereabouts in the interconnected spaces between epithelial cells, i-cells of Hydra and Hydractinia share common features allowing their identification. They are rounded or spindle shaped, possess a large nucleus, a prominent nucleolus, and are rich in ribosomes. I-cells can be stained by basic dyes (Fig $5 \mathrm{~B}$ ). At least a subpopulation is also

A
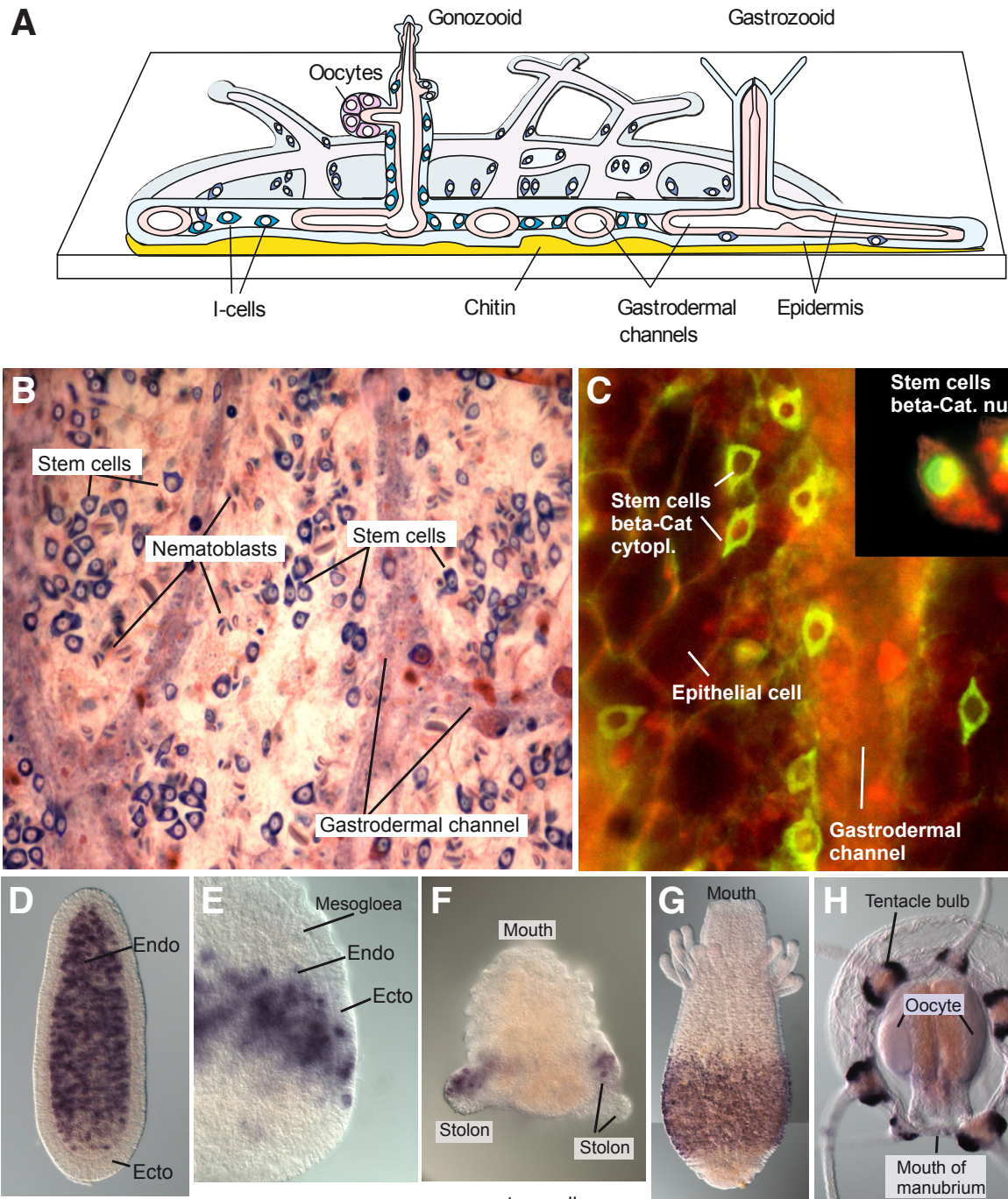
endoderm

channels

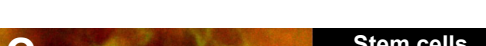

vasa in planula

Fig. 5. Morphology and location of interstitial stem cells (i-cells) in Hydractinia. (A) Structure of the stolon plate of a mature colony with i-cells between two epidermal epithelial layers. The upper epidermal epithelium is translucent and allows detection of i-cells in whole mount preparations. (B) Interstitial stem cells in the stolon mat of Hydractinia, stained with Giemsa (containing basic methylene blue). (A, B from Frank et al., 2009; rights reserved by Springer).(C) anti-beta-catenin immunostaining (green) showing cytoplasmic or nuclear localization in i-cells (preparation by W. Müller, unpubl.). (D-G) Vasa-expressing i-cells in Hydractinia, in endoderm of developing planula (D, 42 hours post-fertilization); in metamorphosis stage at 16 hours when i-cells migrate from endo- to ectoderm while passing the mesoglea (E); at the base of 24 hours primary polyp, just entering the stolons (F); in proximal belt of gastrozooid (G). (H) Vasa-expressing cells in medusa of Podocoryne carnea in the tentacle bulbs and with weaker expression in a belt around the manubrium. (D-G) According to Rebscher et al., 2008 (preparations D-H hitherto unpublished photos by G. Plickert). marked by antibodies to $\beta$-catenin (Fig. 5 C). Interstitial stem cells can be labelled with bromodeoxyuridine (BrdU) and tracked during using transgene technologies in Cnidaria (Miljkovicet al., 2002; Böttger et al., 2002; Wittlieb et al., 2006, Kalthurin et al., 2007; Künzel et al., 2010), the origin, migratory behaviour, multiplication and differentiation of i-cells can now be traced in living animals.

\section{Hydra stem cells and their differentia- tion potential}

In Hydra three distinct cell lineages have been identified (Fig. 6A): The (1) epidermal and the (2) gastrodermal epithelial layers are maintained by epithelial cell proliferation in the middle of the body column. As stated above these cells are not stem cells in classical terms as they are differentiated epithelio-muscle cells. They do, however, preserve the capability of self-renewal (Hobmayer et al., 2012). (3) In spaces between the muscle processes at the bases of both epithelial layers, interstitial stem cells (i-cells) are located. Hydra i-cells are continuously proliferating, multipotent stem cells; they provide an inexhaustible source for the replacement of used up nematocytes, gland cells and aged nerve cells, and provide life-long supplies of germ cells (David and Campbell, 1972; Bode et al., 1973; Campbell and David, 1974; Bode et al., 1976; Bosch and David, 1987; Nishimiya-Fujisawa and Sugiyama, 1993; see also David, 2012; Hobmayer et al., 2012; Nishimiya-Fujisawa, 2012 in this issue).

Differentiation potentials of the stem cell lineages have been studied in "epithelial" animals after elimination of i-cells and by comparing their morphogenetic potentials after re-introducing i-cells. Epithelial hydra are experimentally produced by elimination of the i-cells using irradiation (Brien and Reniers-Decoen, 1955), nitrogen mustard (Diehl and Burnett, 1964), colchicine (Campbell, 1976, 1979), or by hydroxy urea (Bode et al., 1976; Sacks and Davis, 1979). Sf-1, a mutant strain of Hydra magnipapillata (Sugiyama and Fujisawa, 1979; Shimizu, 2012), loses its i-cells after a heat shock. Heat-shock treated individuals develop into an epithelial type animal without chemical interference. Epithelial Hydra, if force-fed, propagate by budding and regenerate lost tissue parts. They are reported to constitute stable lines that continuously last already for over 50 years (Hwang et al., 2007). Regeneration and budding in epithelial Hydra involves extensive conversion of epithelial cell type specificity. Approximately 
20 different cells may arise from monotypic epithelial cells during regeneration indicating inherent stemness properties or at least plasticity to a great extent (Campbell, 1967a,b; Davis, 1970). The conversion of GFP-labelled i-cell-derived zymogen cells into granular mucous cells in the head region of Hydra has been classified as transdifferentiation (Siebert et al., 2008).

Epithelial Hydra were used for i-cell re-population experiments that allowed to analyze differentiation potentials of only a few inoculated interstitial stem cells (David and Murphy, 1977). Though not clearly identifiable by their morphology, members of the i-cell pool in Hydra constitute several subpopulations of apparently precommitted subtypes (David, 2012). Among them are i-cells that are restricted to germ cell differentiation (Littlefield, 1985,
1991; Nishimiya-Fujisawa and Sugiyama, 1993, 1995; Mochizuki et al., 2000; 2001; Nishimiya-Fujisawa, 2012). In order to trace differentiation and migration, labelling of i-cells in S-phase by tritiated thymidine (Campbell and David 1974) and by BrdU was used (Plickert and Kroiher, 1988, Gauchat et al.; 2004; Lindgens et al., 2004; Miljkovic-Licina et al., 2007;). The ontogeny of Hydra i-cells is unknown due to limited accessibility of embryonic development.

\section{Hydractinia larval stem cells and their differentiation potential}

As in Hydra, epithelial cells of Hydractinia proliferate and thus contribute to growth and morphogenesis. In contrast to Hydra, however, in post-embryonic Hydractinia epithelial cells can also form by differentiation from i-cells, and buds of new polyps arise,

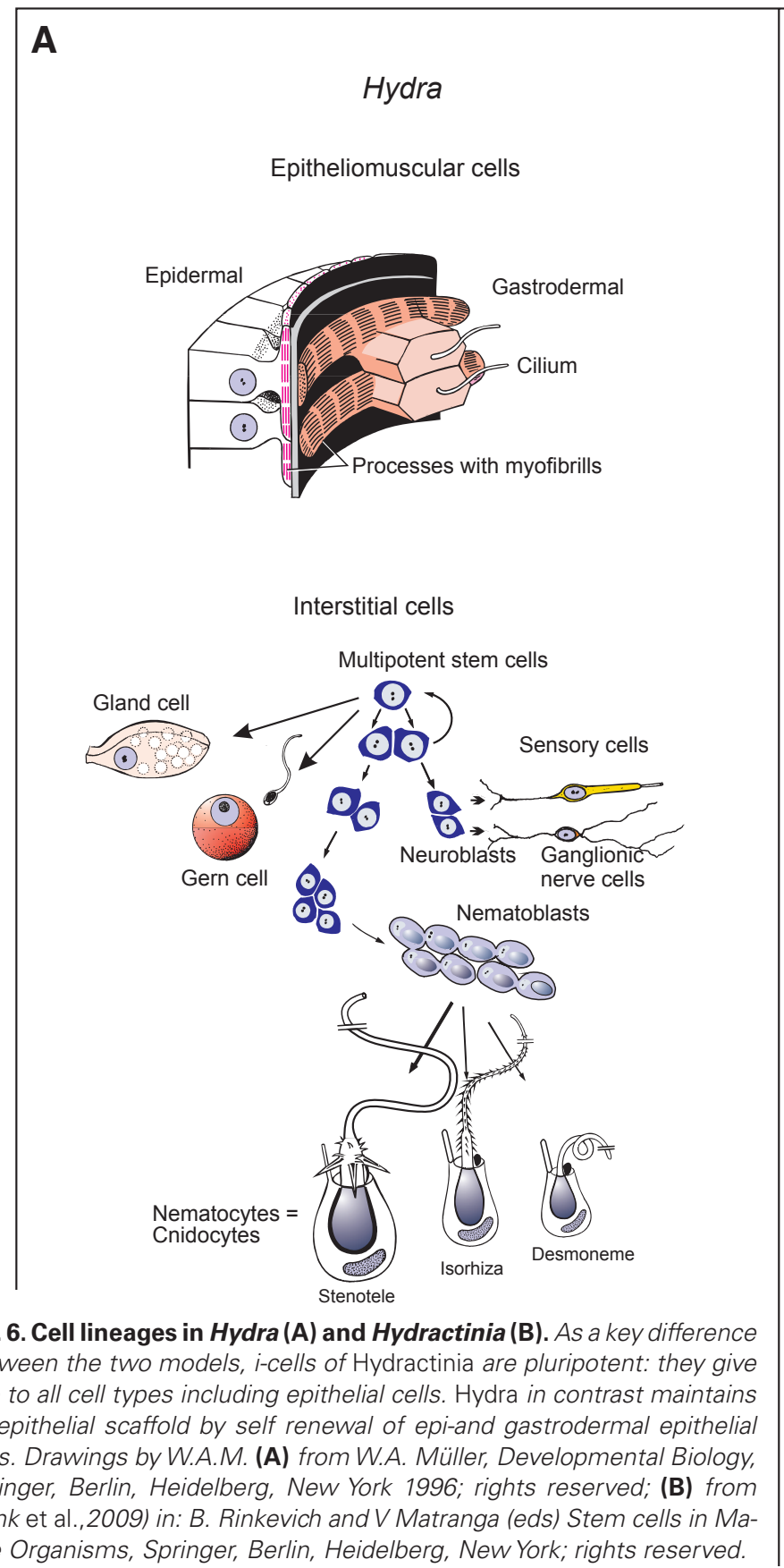

B

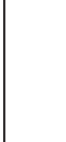

\section{Hydractinia echinata}

Sexual polyp (gonozooid)

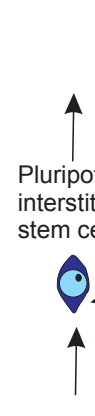

Pluripote
interstitia
stem cells

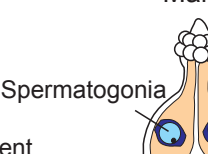

Male

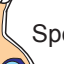

Spermatocytes

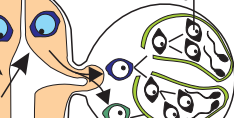
s<smiles>CCCCC</smiles>

(2)

Gonophore

(relict of medusa, gonad)

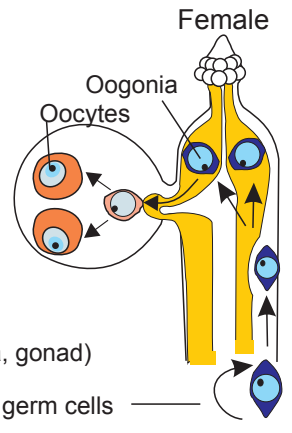

$\odot$
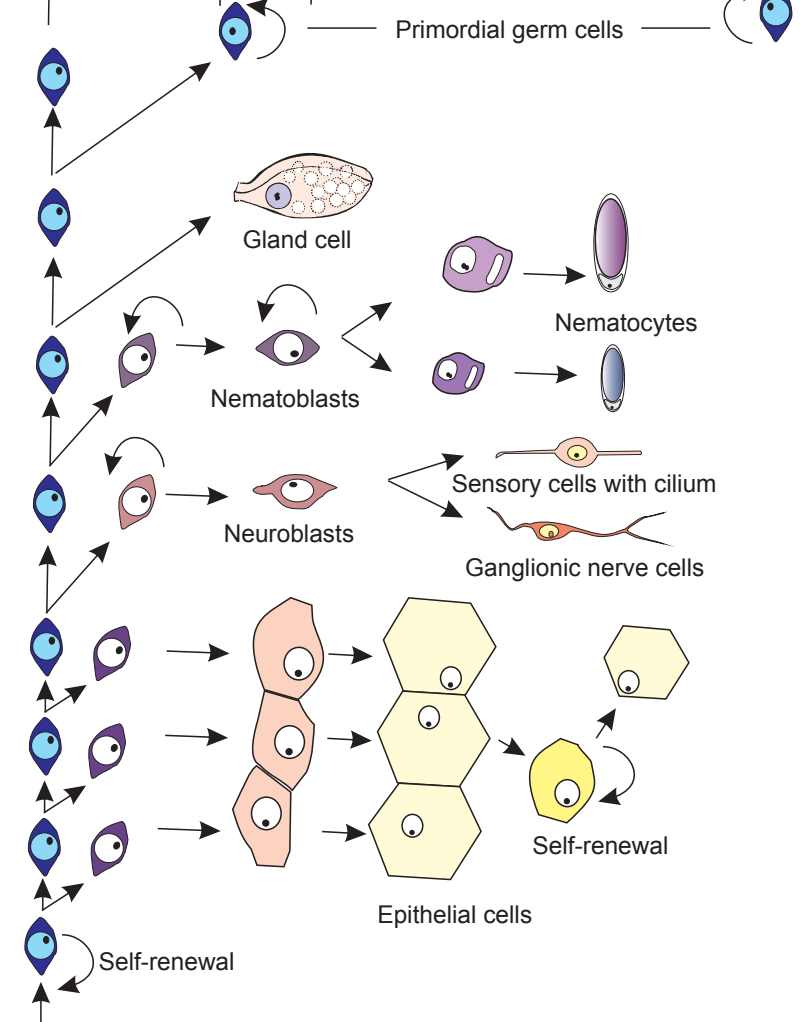

(1)

Pluripotent

interstitial

stem cells 
at least in part, from aggregating i-cells (Fig. 5, and see below).

I-cells derive from the endoderm in Hydractiniaembryos. Already in early post-gastrula, i-cells can be discriminated by morphological criteria from other cell types (Plickert et al., 1988). I-cells acquire stainability for antibodies to Wnt-pathway components at that time (Fig. 5C; Frank et al., 2009). About 24h after fertilization, the stem cell and germ line marker gene Vasa is activated (Rebscheret al., 2008) (Fig. 5D). GFP reporter constructs using the promoters of the Hydractinia genes for Nanos2 or Piwi are expressed at that time, too. In the fully developed three days old planula approximately one tenth of the $12-14,000$ cells are i-cells. They predominantly reside in the gastrodermal cell mass and are the only mitotic cells at this stage (Plickert et al., 1988).

In larval development a fraction of these cells emigrates into the epidermis, giving rise to the larval nervous system and two types of nematocytes: one of which is used to anchor the larvae onto the substrate for settlement, the second is of the same type as the one used in the catching tentacle of the polyp thus preparing polyp life already in larva development. These cells persist during metamorphosis while other larval cells are eliminated by apoptosis (Seipp et al., 2010). During metamorphosis, i-cells cross the mesoglea (van de Vyver 1964; Plickert et al., 1988; Hoffmann and Kroiher, 2001, Rebscher et al., 2008) (Fig. 5E) and colonize new parts of the growing and expanding colony (Fig. 5F), where they give rise to epithelial cells, gland cells, nematocytes, nerve cells and germ cells in the stolon compartment and the polyps (Fig. 5B).

\section{Adult stem cells and their differentiation potential}

Adult Hydractinia colonies lodge i-cells in three epidermal compartments: (1) in the polyp, confined to a broad belt in the mid-gastric region (Fig. 5G) and thus similar to the distribution of i-cells in Hydra (David and Plotnick, 1980). (2) Asecond population of $\mathrm{i}$-cells emigrates into the stolons during and post metamorphosis (Fig. 5 A,F). They provide the source for new epithelial cells in the stolon and polyp buds (for detail see below), nematocytes and primordial germ cells. (3) I-cells occur at high numbers also in the stolonal mat (5 A-C). They contribute to polyp budding and serve the recruitment of gland cells, nematocytes, nerve cells and primordial germ cells (Fig. 6).

The differentiation potential of the adult stem cells in Hydractinia has been analyzed by elimination of these cells and their replacement by isogeneic or allogeneic donor stem cells. Colonies were deprived of their own i-cells by treating the recipient colonies with alkylating agents such as mitomycin C. Without stem cells the colonies survive about 4 weeks. Before dying, i-cell-free recipient colonies were repopulated by transplanting a small piece of stolon tissue from healthy isogeneic colonies or from allogeneic, histocompatible donors of the opposite sex. After emigration of stem cells the donor transplant was removed. With time, the repopulated colonies recovered and transformed into the phenotype of the donor, including its sex (Müller, 1967). The experiment was repeated using mutant phenotypes such as multiheaded polyps (Fig. 2D) or colonies showing autoaggressive behaviour. Only small and transitory bridges of epithelial tissue allowed the immigration of BrdU-labelled i-cells from donor tissue into the i-cell-depleted recipients.

Upon replacement of their interstitial stem cells, mutant phenotypes were converted into wild type phenotypes, and conversely, wild-type colonies into mutant forms (Müller et al., 2004a). The conversion followed a distinct temporal pattern (Fig. 6) and always included the gametes: originally female colonies produced sperm; originally male colonies spawned eggs. BrdU-labelled epithelial cells were observed in the recipients and their complete phenotype was converted into the phenotype of the donor including genetically determined traits such as multi-headed polyps, histocompatibility loci and the sex of their gametes. It was therefore concluded that i-cells are pluripotent/totipotent (since in Cnidaria no extraembryonic tissues exist, the terms pluripotent and totipotent can be used synonymously).

The migratory behaviour and the differentiation potential of i-cells was re-analyzed using transgenic donors expressing GFP under the epithelial cell type specific Actinl-promoter. Transgenic animals do not show any GFP labelled i-cells, nematocytes, gland cells or nerve cells (Künzel et al., 2010). In Hydra, GFP expressing epithelial cells of both germ layers migrate fast as they change axial positions from a midgastric implant to the tentacles within only 5 days, and endodermal epithelial cells migrate individually to contribute to the tissue of new buds (Wittlieb et al., 2006). In contrast, Hydractinia epithelial cells are stationary. Time-lapse movies and long term observations of GFP-labelled epithelial cells in epidermis and gastrodermis of Hydractinia did not detect any individual migration behaviour.

\section{Aggregation of stem cells as a preparatory step in polyp budding}

Tissue fusion experiments between transgenic donors and wild type colonies led to the identification of rapidly moving (approximately 100-150 $\mu \mathrm{m} /$ day) donor cells, which expressed GFP once they stopped moving and differentiated into epithelial cells, thereby activating the epithelial-specific promoter of the GFP transgene. Clusters of epithelial cells were newly formed from migratory icells at sites where subsequently polyp buds emerged (Künzel et al., 2010). Forced activation of the Wnt pathway not only evokes the production of numerous nematocytes and nerve cells, and the formation of supernumerary ectopic tentacles in growing and full grown polyps (Müller et al., 2007; Plickert et al., 2006; Teo et al., 2006), but also stimulates budding frequencies. Polyp buds emerge in higher numbers and shorter distances, presumably supported in part by enhanced multiplication of stem cells, which prepare bud formation by aggregation. Increased populations of stem cells would allow budding at shorter distances (Müller et al., 2007). Thus, budding distances may not only be determined by inhibitory signals emanating from existing polyps (as indicated in Fig. 3B) but also by the availability of precursor stem cells.

\section{Specification of germ cells and sex determination}

Specification of germ cells and sex determination are major themes in developmental and evolutionary biology. Depending on the animal group, germ line specification may either be controlled by inherited maternal factors, or by inductive signals (Extavour and Akam, 2003). In several model organisms, such as Caenorhabditis elegans, Drosophila melanogasterand Xenopus laevis, primordial germ cells are specified and set aside very early in embryogenesis initiated by maternal signals. By contrast, in Hydractinia, adult stem cells preserve pluripotency and thus the capability to give rise to germ cells throughout life, probably enabled by Oct4-like POU factors (Millane et al., 2011), by Vasa (Rebscher et al., 2008), Piwi (called Cniwi in Podocoryne carnea; Seipel et al., 2004b; 
this report, Table 1), Nanos and Myc2 (this report, Table 1), like in many bilaterians (Extavour et al., 2005). Sex determination is upstream of germ cell specification, and is stem cell autonomous rather than being induced by signals from somatic tissues. This is evident from experiments showing that transplantation of adult male stem cells to adult female recipients causes sex reversal (Müller, 1964, 1967). Hence, the sexual polyps probably emit a signal instructing pluripotent cells of a defined sex to enter gametogenesis. Furthermore, gonads containing male and female gametes, simultaneously, have been reported (Mali et al., 2011).

In Hydractinia, Vasa and Piwi are stem cell genes expressed in polyp and stolonal i-cells and in primordial germ cells migrating into gonads in statu nascendi (Rebscher et al., 2008; this report) (Table 1). Vasa expression is rather strong in i-cells at the base of primary polyps (Fig. 5F) but is weak or absent from i-cells migrating through interstices of the gonozooid. Only when approaching the axial level of gonad development, expression is dramatically upregulated. This is consistent with the expression of Vasa in Hydra (Mochizuki et al., 2001). Migrating i-cells in the stolons show a low expression for two other stem cell related genes, Piwi and Nanos2, as evident from the expression of GFP reporter constructs driven by the respective or cell type specific promoters. Like Vasa, Piwi is strongly upregulated in primordial germ cells of Hydractinia.

The pattern of Piwi expression is not known in Hydra but another putative stem cell/germ line gene, Nanos1, shows similar bimodal expression levels in stem cells, nematoblasts and gametogenesis (Mochizuki et al., 2000). Cniwi (Piwi) of Podocoryne carnea is expressed in the gonads but it is not clear which cells in Podocoryne give rise to gametes (Seipel et al., 2004b). In Clytia hemisphaerica, Piwi expression was observed in nematogenic/neurogenic stem cells in the tentacle bulbs of the medusa (Denker et al., 2008), strongly suggesting a role of this gene in a uncommitted subpopulation of putative multipotent stem cells, perhaps similar to the nematogenic/neurogenic i-cell population in Hydractinia. Remarkably, in the medusa of Podocoryne, Vasa is strongly expressed laterally in the tentacle bulbs (Fig. $5 \mathrm{H})$ and thus in the same location Piwi is expressed in Clytia medusae. The transgene expression data for Nanos and Piwi in migrating stolonal i-cells corroborate the notion derived from repopulation experiments mentioned above that this i-cell population includes pluripotent stem cells and that low expression of Nanos and Piwi is a common feature of them. Once the germ cell precursors have been committed, Vasa and Piwi are strongly upregulated. In oogonia a cell-type specific polymorphic thrombospondin domain-containing lectin is expressed which may fulfill functions in fertilization (Mali et al.,2011).

\section{Reprogramming of differentiated cells in hydrozoans}

\section{Reprogramming of epithelial cells into stem cells in Hydractinia}

Millane et al., 2011) analyzed the expression and function of a POU-domain gene from Hydractinia echinata with high sequence similarity to the mammalian Oct4. Oct4 is a well-known pluripotency factor expressed in the inner cell mass, epiblast and germ line of mammals. In Hydractinia the Oct4-like gene, Polynem $(P I n)$, is expressed in the embryo and stem cells. Downregulation of the gene by retinoic acid or RNAi lead to differentiation into nematocytes. PIn is a target of its own protein together with other transcription factors, like SoxB, Tcf, Vasa and Piwi. Its function as a pluripotency maintaining transcription factor becomes evident by its ectopic expression in epithelial cells under the control of the epithelial cell-specific Actin1 promoter. Actl::PIntransgenic animals transform epithelial cells into i-cell-like cells in vivo. Transformed cells form neoplasms that in a primary stage consist entirely of i-cells and by aging contain more and more differentiated cell types (i.e., nematocytes and epithelial cells) (Fig. 7). Neoplasms show an iterative cycling between epithelial cells and i-cells that differentiate either into nematocytes or into epithelial cells. The latter reactivate the transgene and reiterate a novel pluripotency induction cycle. These results push back the history of POU-mediated pluripotency at least to the common ancestor of cnidarians and bilaterians, suggesting it to be a basal feature in metazoans.

\section{Transdifferentiation of striated muscle into stem cells and germ cells in Podocoryne}

Division of labor is driven to perfection in Hydrozoa with a complete metagenetic life cycle, such as in Podocoryne carnea, as they display a particularly evolved free-living form, the medusa (jellyfish). Medusae differentiate sensory organs and muscles that do not have any counterparts in polyps: They are able to perceive light and/or gravity stimuli, and - as in the medusa of Cladonema radiatum - are even set with eye spots at the base of their tentacles. Cladonema as well as the eyeless Podocoryne medusa

TABLE 1

STEM CELL RELATED GENES EXPRESSED IN HYDRACTINIA AND SELECTED COLONIAL HYDROZOA

\begin{tabular}{|c|c|c|c|}
\hline Gene & Species & Sites of expression & References \\
\hline Wnt3a & Hydractinia echinata & i-cells, epidermis, gastric region of polyps & Müller et al., 2007 \\
\hline Frizzled & Hydractinia echinata & i-cells, epidermis, gastric region of polyps, stolon & Teo et al., 2006 \\
\hline B-Catenin & Hydractinia echinata & i-cells, stolon, i-cell precursors in post-gastrula (endoderm) & Teo et al., 2006, this report \\
\hline \multirow[t]{2}{*}{ Vasa } & Hydractinia echinata & i-cell precursors (endoderm), i-cells in stolon and polyp (epidermis), germ cell precursors & Rebscher et al., 2008 \\
\hline & Podocoryne carnea & nematogenic stem cell in tentacle bulbs of medusa (epidermis), germ cell precursors & This report \\
\hline \multirow[t]{3}{*}{ Piwi } & Hydractinia echinata & i-cells in stolon and polyp, germ cell precursors & This report \\
\hline & Podocoryne carnea & gonads, proliferating cells in tentacle bulbs (nematogenic stem cells) and in manubrium & Seipel et al., 2004 \\
\hline & Clytia hemisphaerica & nematogenic/neurogenic stem cells in tentacle bulbs & Denker et al., 2008 \\
\hline Nanos2 & Hydractinia echinata & i-cells, stolon and polyp, nematogenic/neurogenic stem cell, gametogenic cells & Kanska and Frank, 2011 \\
\hline SRF (Serum response factor) & Hydractinia echinata & i-cell precursors (endoderm), i-cells in stolon and polyp (epidermis), gametogenic cells & Hoffmann and Kroiher, 2001 \\
\hline Pln (Pou-protein) & Hydractinia echinata & i-cells, stolon, induced pluripotent stem cells & Millane et al., 2011 \\
\hline Myc2 & Hydractinia echinata & i-cells, stolon, induced pluripotent stem cells & Kanska and Frank, 2011 \\
\hline
\end{tabular}




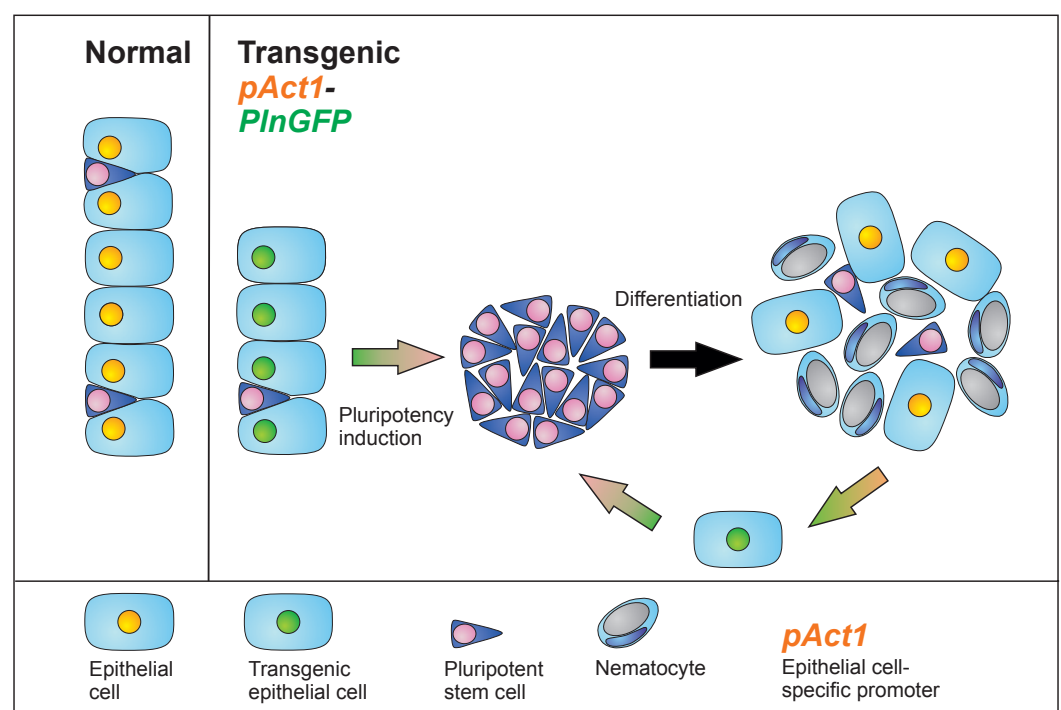

Fig. 7. A model of pluripotency induction by the POU protein PIn in Hydractinia echinata. Ectopic expression of the POU protein PIn under the epithelial cell-specific Actin1 promoter causes the formation of neoplasms consisting of pluripotent stem cells. They express the endogenous PIn, Nanos, Vasa, Piwi and Myc2 but switch off the epithelial-specific pAct1-PInGFP transgene. Over time most stem cells in neoplasms differentiate into epithelial cells and nematocytes, a process that can be accelerated by retinoic acid or PIn RNAi. Once cells become epithelial they shut down their endogenous PIn but reactivate the pAct1-PInGFP transgene and reiterate a new cycle of pluripotency induction and consecutive differentiation. After Millane et al., 2011.

express members of the eye-specific Sine oculis/Six class family of homeobox genes (Stierwald et al., 2004). Swimming activity is enabled by striated muscle in the subumbrella, a tissue layer derived from the entocodon. In the developing medusa, this structure is found between derivatives of the ectoderm and the endoderm. Moreover, the entocodon and its descendant cells express genes considered to be mesodermal/myogenic in triploblastic animals like Twist, Brachyury, Mef2, and Snail (Spring et al., 2000, 2002), in addition to several homeobox genes (Otx, Cnox1-Pc, Cnox3-Pc), a $M y o D$-like muscle-differentiation gene, a specific splice variant of the myosin heavy chain gene (Myo1), and tropomyosin (Tpm2) (Yanze et al., 1999; Muller et al., 2003). It has therefore been proposed that the entocodon is equivalent to mesoderm (Muller et al., 2003; Seipel and Schmid, 2005, 2006), but this issue is controversial because the entocodon is not formed during embryogenesis when the other germ layers are formed.

In hydroids an unmatched power of dedifferentiation and transdifferentiation even without previous genetic interference has been discovered. Isolated, mononucleated, cross-striated muscle cells of a medusa can transdifferentiate in vitro to various new cell types and even form a complex regenerate (Schmid et al., 1982, 1993; Alder and Schmid, 1987; Schmid and Plickert, 1990, Schmid and Reber-Müller, 1995; Yanze et al., 1999). The transdifferentiation events follow a strict pattern (Schmid, 1992). The first new cell type resembles smooth muscle and forms without a preceding DNA replication. These cells behave like multipotent stem cells. With the exception of striated muscle cells, all cell types are formed: nematocytes, nerve cells, epithelial cells and germ cells. Some preparations develop an inner and an outer layer separated by a basal lamina followed by regeneration of a manubrium, the medusa feeding organ.

\section{Migrating stem cells and the evolution of histo- incompatibility}

\section{Competition behaviours between Hydractinia colonies}

Hydractinia has evolved the capability of recognizing allogeneic neighbors and to prevent ingression of allogeneic stem cells, which could colonize the gonads and differentiate to gametes at the expense of resident cells. Primarily, the ability to identify foreign tissue may have evolved as a prerequisite to combat neighbors competing for the habitat - an association that may appear strange in the context of stem cell biology. The explanation presupposes a brief review on the phenomenon known as allorecognition (Rosengarten and Nicotra, 2011).

Space on marine hard substrata is limited. This applies in particular to shells inhabited by hermit crabs on which Hydractinia and Podocorynelarvae preferentially settle. Expanding colonies can grow into contact with competitors. Physical contact between two neighboring colonies is accomplished by the advancing tips of the peripheral, runner-like stolons. Like the terminal cells of growing blood vessels, these motile tips have path-finding functions. If growing into contact with other stolonal tissue, three types of reactions can be observed, depending on the genetic relatedness of the interacting individuals:

(1) Provided the neighboring stolon tissue is part of the same colony or of its cloned descendants (isogeneic encounters) the tips stop moving and permanently fuse with the contacted tissue (Fig. 3 D-1). Fusion can also occur between allogeneic tissues resulting in a common chimeric colony, mostly restricted to close kin (Hauenschild, 1954, 1956), which share at least one alr locus (Nicotra et al., 2009; Rosa et al., 2010; Rosengarten et al., 2011; Rosengarten and Nicotra, 2011).

(2) In most cases, however, allogeneic encounters lead to dramatic outcomes. The contacting colonies do not fuse. Instead they mount a defense system based on a peculiar type of stinging cell (microbasic mastigophore). These occur exclusively in the stolon compartment and are not used to catch prey. Upon histoincompatible contacts their differentiation from pluripotent stem cells is induced thus increasing their frequency from normally one per $\mathrm{mm}$ stolon length up to 400 per $\mathrm{mm}$ in the so-called hyperplastic stolons of incompatible colonies (Lange et al., 1989). In the course of tissue rejection combat, microbasic mastigophores are recruited from distant areas, migrate quickly to and accumulate at contact sites (Fig. 3 D-2). Here, the stinging cells turn around, directing their sensory cnidocil to the encountered neighbor, and synchronously discharge their toxins into its tissue. Mutual attacks are repeated until only one competitor survives (Lange et al., 1989, 1992; movie: Müller, 1996). A member of the COUP family of transcription factors is expressed in the contact area (Duffy and Frank, 2011).

(3) Mutual attacks are accompanied by the occurrence of many hyperplastic stolons at contact sites due to the action of the stoloninducing factor, SIF. Whenever an advancing stolon tip approaches the flank of another stolon, the tip releases a factor that induces the local formation of second tip in the opposing stolon as shown in Fig. 3 C,D (Müller et al., 1987; Lange and Müller, 1991). Both 
the inducing and the induced tip move towards each other, but do not fuse and form an anastomosis, when they do not share an alr locus and therefore belong to different histocompatibility types. Instead, incompatible tips continue to move and begin to attack their neighbor using their nematocytes. These are recruited also in compatible encounters but do not discharge and eventually disperse.

\section{Regulators of allorecognition in Hydractinia}

Genetic analyses were impeded by the occurrence of several types of transitory fusion (Buss et al., 1984) and of genotypes displaying even autoaggressive behaviour attacking and destroying areas of its own tissue (Müller, 2002). Although first pioneering genetic analyses date back several decades (Hauenschild, 1954, 1956 in $H$. echinata) only extensive positional cloning of two allorecognition loci alr1 and alr2 in $\mathrm{H}$. symbiolongicarpus (Mokady and Buss 1996; Cadavid et al., 2004; Schwarz et al., 2007; Nicotra et al., 2009; Rosa et al., 2010; Rosengarten et al., 2011; Rosengarten and Nicotra, 2011) eventually provided evidence for the involvement of molecules belonging to the immunoglobulin superfamily. In 2009 a first gene was identified that encodes a putative transmembrane receptor expressed in all tissues capable of allorecognition. It is highly polymorphic and gives rise to a previously undescribed hypervariable protein bearing three extracellular domains with significant sequence similarity to the immunoglobulin superfamily, which is known to encode allodeterminants in other animals (Nicotra et al., 2009). However, like in the MHC-mediated allorecognition system of vertebrates, the individual identity is not encoded by a single polymorphic gene but by clusters of paralogous alrgenes (Rosengarten et al., 2011; Rosengarten and Nicotra, 2011).

\section{Origin(s) of allorecognition in Hydractinia}

Like in vertebrates, the allorecognition system in Hydractinia allows transplantation only between compatible colonies. Incompatible transplants are rejected not only from the stolonal environment, but also from all post-metamorphic tissues. Allotolerance is not induced in chimeric embryos in most cases (Lange et al., 1992; Fuchs et al., 2002; Poudyal et al., 2007), although Fuchs et al., (2002) provided evidence for coexistence of incompatible allogeneic cells in a single chimera post metamorphosis. Therefore the system is innate and does not parallel acquired immunity in vertebrates. Competition for space was likely not the only selective pressure driving the evolution of histocompatibility in these species (and other clonal sessile invertebrates). In case of compatible encounters fusion can occur also between male and female colonies. In such chimeric colonies interstitial stem cells can easily invade the partner. By introducing foreign genes, immigrating stem cells could transform the characteristics of the host as shown in the repopulation experiments outlined above. Moreover, since i-cells can give rise to germ cells, foreign i-cells could transmit foreign genes instead of host genes to descendants. In Hydractinia echinata the faster and continuously dividing male primordial germ cells usually outnumber and displace the oogonia from the sexual polyps thus causing sex reversal in the originally female partner (Müller, 1964, 1967; Müller et al., 2004a,b). Therefore, it has been proposed that histo-incompatibility evolved to prevent germ cell parasitism (Buss, 1982).

\section{Outlook}

With the completion of the genomic database of Hydractinia, which we expect soon, and the availability of transgenic methods as reviewed here, we intend to elucidate the pluripotency transcriptional network in this basic metazoan species, including the specific functions of each of the key genes. This will have major implications on the study of stem cell evolution and ancestral stem cell gene regulatory networks. It is evident that genes like Nanos, Vasa and Piwi are stem cell genes in Hydractinia, but are also expressed in germ cells. It will be of high interest to dissect the stem cells of Hydractinia in respect to subpopulations, which may differ in their developmental potential. Data outlined in this review suggest that the control of stemness and pluripotency is coupled to these genes and also to PIn and Myc. A key aspect will be the fundamental decision between stemness and thus active cycling on the one hand, and differentiation on the other hand. Closely related to this: how do these animals so perfectly manage to avoid aging and cancer? It is therefore promising to study the role of these stem cell genes in asymmetric cell divisions of pluripotent stem cell. The apparent flexibility of cnidarian cells may suggest that epigenetic modifications are of minor importance in these species compared to vertebrates, at least in some cell types. In this respect it will be of interest to analyze genes known to act as epigenetic modifiers that are present in the Hydractinia genome. Hopefully, studies in Hydrozoa may assist developing new methods for tissue culture from adult stem cells in regenerative medicine, like they once played a pioneering role in stem cell biology.

\section{Acknowledgements}

We thank Brigitte Galliot for critical reading of the manuscript. Studies on Hydractinia have been supported by the German Research Foundation, DFG (W.A.M. and G.P.) and by Science Foundation Ireland (U.F.).

\section{References}

ALDER, H. and SCHMID, V. (1987). Cell cycles and in vitro transdifferentiation and regeneration of isolated, striated muscle of jellyfish. Dev. Biol. 124: 358-369.

BERKING, S. (1987). Homarine (N-methylpicolinic acid) and trigonelline (N-methylnicotinic acid) appear to be involved in pattern control in a marine hydroid. Development 99: 211-220.

BERKING, S. (1988). Taurine found to stabilize the larval state is released upon induction of metamorphosis in the hydrozoan Hydractinia echinata. Roux's Arch. Dev. Biol. 197: 321-327.

BODE, H.R. (1996). The interstitial cell lineage of hydra: A stem cell system that arose early in evolution. J. Cell Sci. 109: 1155-1164.

BODE, H., BERKING, S. and DAVID, C. N. (1973). Qanatitative analysis of cell types during growth and morphogenesis in hydra. Roux'Arch. Dev. Biol. 171: 269-285.

BODE, H.R., FLICK, K.M. and SMITH, G.S. (1976). Regulation of interstitial cell differentiation in Hydra attenuata. I. Homeostatic control of interstitial population size. J. Cell Sci. 20: 29-46.

BOELSTERLI, U. (1977). An electron microscopic study of early developmenta stages, myogenesis, oogenesis and cnidogenesis in the anthomedusa, Podocoryne carnea M. Sars. J. Morphol. 154: 259-89.

BOETTGER, A., ALEXANDROVA, O. and CIKALA, M. (2002). GFP expression in Hydra: Lessons from the particle gun. Dev. Genes Evol. 212: 302-305.

BOSCH, T.C.G. (2007). Why polyps regenerate and we don't: Towards a cellular and molecular framework for Hydra regeneration. Dev. Biol. 303: 421-433.

BOSCH, T.C.G. (2009). Hydra and the evolution of stem cells. BioEssays 31: 478-486. BOSCH, T.C.G., ANTON-ERXLEBEN, F. and HEMMRICH, G. (2010). The Hydra 
polyp: Nothing but an active stem cell community. Dev. Growth Differ. 52: 15-25.

BOSCH, T.C. and DAVID, C.N., 1987. Stem cells of Hydra magnipapillata can differentiate somatic and germ cell lines. Dev. Biol. 121, 182-191.

BRIEN, P. and RENIERS-DECOEN, M. (1955). The significance of the interstitial cells of the fresh water Hydra and the problem of the embryonic reserve. Foreign title: La signification des cellules interstitielles des hydres d'eau douce et le probleme da la reserve embryonnaire. Bull. Biol. France et Belgique 89: 258-325.

BROUN, M., GEE, L., REINHARDT, B. and BODE, H. (2005). Formation of the head organizer in hydra involves the canonical Wnt pathway. Development 132: 2907-2916.

BUSS, L.W. (1982). Somatic cell parasitism and the evolution of somatic tissue compatibility. Proc. Nat. Acad. Sci. USA 79: 5337-5341.

BUSS, L.W., MCFADDEN, C.S. and KEENE, D.R. (1984). Biology of hydractiniid hydroids. 2. Histcompatibilty effector system competitive mechanisms mediated by nematocyst discharge. Biol. Bull. 167: 139-158.

CADAVID, L.F., POWELL, A.E., NICOTRA, M.L., MORENO, M. and BUSS, L.W. (2004). An invertebrate histocompatibility complex. Genetics 167: 357-365.

CAMPBELL, R.D. (1967a). Tissue dynamics of steady state growth in Hydra littoralis. I. Pattern of cell divisions. Dev. Biol. 15: 487-502.

CAMPBELL, R.D. (1967b). Tissue dynamics of steady state growth in Hydra littoralis. II. Patterns of tissue movements. J. Morphol. 121: 19-28.

CAMPBELL, R.D. (1976). Elimination of hydra interstitial and nerve cells by means of colchizine. J. Cell Sci. 21:1-13

CAMPBELL, R.D. (1979). Development of hydra lacking interstitial and nerve cells ("epithelial hydra"). In: Subtelny S., Konigsberg I.R. (eds): Determinants of spatial organization, 37th Symp. Soc. Dev. Biol., p267-293, Academic Press, New York, London

CAMPBELL, R.D. and DAVID, C.N. (1974). Cell cycle kinetics and development of Hydra attenuata. Part 2: Interstitial cells. J. Cell Sci. 16: 349-358.

CARTWRIGHT, P., SCHIERWATER, B. and BUSS, L.W. (2006). Expression of a Gsxparahox gene, Cnox-2, in colony ontogeny in Hydractinia (Cnidaria: Hydrozoa). J. Exp. Zool. 306B: 460-469.

CHAPMAN, J.A., KIRKNESS, E.F., SIMAKOV, O. et al.,2010). The dynamic genome of Hydra. Nature 464: 592-596

CHIORI, R., JAGER, M., DENKER, E., WINCKER, P., DA SILVA, C., LE GUYADER, H., MANUEL, M. and QUEINNEC, E. (2009). Are Hox genes ancestrally involved in axial patterning? Evidence from the hydrozoan Clytia hemisphaerica (Cnidaria). PLOS ONE 4: e4231.

COLLINS, A.G., SCHUCHERT, P., MARQUES, A.C., JANKOWSKI, T., MEDINA, M. and SCHIERWATER, B. (2006). Medusozoan phylogeny and character evolution clarified by new large and small subunit rDNA data and an assessment of the utility of phylogenetic mixture models. Syst. Biol. 55: 97-115.

DAVID, C.N. (2012). Interstitial stem cells in Hydra: multipotency and decision-making. Int J Dev Biol 56: 489-497.

DAVID, C.N. and CAMPBELL, R.D. (1972). Cell cycle kinetics and development of Hydra attenuata. I. Epithelial cells. J. Cell Sci. 11, 557- 568.

DAVID, C.N. and MURPHY, S. (1977). Characterization of interstitial cells in hydra by cloning. Dev. Biol. 58: 372-383.

DAVID, C.N. and PLOTNICK, I. (1980). Distribution of interstitial stem cells in Hydra attenuata. Dev. Biol. 76: 175-184.

DAVIS, L.E. (1970). Cell division during dedifferentiation and redifferentiation in regenerating isolated gastrodermis of hydra. Exp. Cell Res. 60: 127-132.

DENKER, E., MANUEL, M., LECLERE, L.,LE GUADER, H. and RABET, N. (2008). Ordered progression of nematogenesis from stem cells through differentiation stages in the tentacle bulb of Clytia hemisphaerica. Dev. Biol. 315: 99-113.

DIEHL, F.A. and BURNETT, A.L. (1964). The role of interstitial cells in the maintainance of hydra: I. Specific destruction of interstitial cells in normal, asexual, and non-budding animals. J. Exp. Zool. 155: 253-259.

DUFFY, D.J. and FRANK, U. (2011). Modulation of COUP-TF expression in a cnidarian by ectopic Wnt signalling and allorecognition. PLoS One 6: Article No.: e19443.

DUFFY, D.J., PLICKERT, G., KUENZEL, T., TILMANN, W. and FRANK, U. (2010). Wnt signaling promotes oral but suppresses aboral structures in Hydractinia metamorphosis and regeneration. Development 137: 3057-3066.

EXTAVOUR, C.G. and AKAM, M. (2003). Mechanisms of germ cell specification across the metazoans: epigenesis and preformation. Development 130: 5869-5884.

EXTAVOUR, C.G., PANG, K., MATUS, D.Q. and MARTINDALE, M.Q. (2005). Vasa and nanos expression patterns in a sea anemone and the evolution of bilaterian germ cell specification mechanisms. Evol. Dev. 7: 201-215.

FINNERTY, J.R., PANG, K., BURTON, P., POULSON, D., and MARTINDALE, M.Q. (2004). Origins of bilateral symmetry: Hox and dppexpression in a sea anemone. Science 304: 1335-1337.

FITT, W.K., COON, S.L., WALCH, M., WEINER, R.M., COLWELL, R.R. and BONAR, D.B. (1990). Settlement behaviour and metamorphosis of oyster larvae (Crassostrea gigas) in response to bacterial supernantants. Mar. Biol. 106: 389-394.

FRANK, U., PLICKERT, G. and MÜLLER, W.A. (2009). Cnidarian interstitial cells: the dawn of stem cell research. In: RINKEVICH, B., MATRANGA, V. (eds) Stem cells in marine organisms. Springer, Berlin, Heidelberg, New York, Tokyo.

FRANK, U., LEITZ, T. and MÜLLER, W.A. (2001). My favourite model organism: Hydractinia echinata. BioEssays 23: 963-971.

FREEMAN, G. (1987). The role of oocyte maturation in the ontogeny of fertilization site in the hydrozoan Hydractinia echinata. Roux's Arch. Dev. Biol. 196: 83-92.

FRITZENWANKER, J,H., GENIKHOVICH, G., KRAUS, Y. and TECHNAU, U. (2007) Early development and axis specification in the sea anemone Nematostella vectensis. Dev. Biol. 310: 264-279.

FRÖBIUS, AC., GENIKHOVICH, G., KÜRN., U., ANTON-ERXLEBEN, F. and BOSCH T.C.G. (2003). Expression of developmental genes during early embryogenesis of Hydra. Dev. Genes Evol. 213: 445-455.

FUCHS, M-A., MOKADY, O. and FRANK, U. (2002). The ontogeny of allorecognition in a colonial hydroid and the fate of early established chimeras. Int. J. Dev. Biol. 46: 699-704.

GAJEWSKI, M., LEITZ, T., SCHLOSSHERR, J. and PLICKERT, G. (1996). LWamides from Cnidaria constitute a novel family of neuropeptides with morphogenetic activity. Roux's Arch. Dev. Biol. 205(5-6): 232-242.

GAUCHAT, D., ESCRIVA, H., MILJKOVIC-LICINA, M., CHERA, S., LANGLOIS, M.C., BEGUE, A., LAUDET, V. and GALLIOT, B. (2004).The orphan COUP-TF nuclear receptors are markers for neurogenesis from cnidarians to vertebrates. Dev. Biol. 275: 104-123.

GAUCHAT, D., MAZET, F., BERNEY, C., SCHUMMER, M., KREGER, S., PAWLOWSKI, J., and GALLIOT, B. (2000). Evolution of Antp-class genes and differential expression of HydraHox/paraHox genes in anterior patterning. Proc. Nat. Acad. Sci. USA 97: 4493-4498.

HAUENSCHILD, C. (1954). Genetical and physiological investigations on intersexuality and histocompatibility in Hydractinia echinata. (Foreign title: Genetische und entwicklungsphysiologische Untersuchungen über Intersexualität und Gewebeverträglichkeit bei Hydractinia echinata Flem. (Hydroz. Bougainvill.). Wilhelm Roux' Archiv fuer Entwicklungsmechanik der Organismen. 147: 1-41.

HAUENSCHILD, C. (1956). On the heredity of a histocompatibility characteristic in the hydropolyp Hydractinia echinata (Foreign title: Über die Vererbung einer Gewebeverträglichkeits-Eigenschaft bei dem Hydroidpolypen Hydractinia echinata.) Zeitschrift für Naturforschung 11b: 132-138.

HOBMAYER, B., RENTZSCH, F., KUHN, K., HAPPEL, C.M., CRAMER VON LAUE C., SNYDER, P., ROTHBÄCHER, U. and HOLSTEIN, T.W. (2000). Wnt signalling molecules act in axis formation in the diploblastic metazoan Hydra. Nature 407: 186-189

HOBMAYER, B., JENEWEIN, M., EDER, D., GLASAUER, S., GUFLER, S., HARTL, M. and SALVENMOSER, W. (2012). Stemness in Hydra - a current perspective. Int J Dev Biol 56: 509-517.

HOFFMANN, U. and KROIHER, M. (2001) A possible role for the cnidarian homologue of serum response factor in decision making by undifferentiated cells. Dev. Biol. 236: 304-315

HOULISTON, E.; MOMOSE, T. and MANUEL, M. (2010) Clytia hemisphaerica: a jellyfish cousin joins the laboratory. Trends Genet. 26: 159-167.

HWANG, J.S., OHYANAGI, H., HAYAKAWA, S., OSATO, N., NISHIMIYA-FUJISAWA, C., IKEO, K., DAVID, C., FUJISAWA, T. and GOJOBORI, T. (2007). The evolutionary emergence of cell type-specific genes inferred from the gene expression analysis of Hydra. Proc. Nat. Acad. Sci. USA 104: 14735-14740.

KANSKA, J. and FRANK, U. (2011). An ancient role for Nanos in axial patterning. Abstract. Int. Workshop: Searching for Eve, Basal Metazoans and the Evolution of Multicellular Complexity. 
KANSKA, J. and FRANK, U. (2011). Generating a monster by an oncogene: Myc ectopic expression in Hydractinia. Abstract. Int. Workshop: Searching for Eve, Basal Metazoans and the Evolution of Multicellular Complexity.

KHALTURIN, K., ANTON-ERXLEBEN, F., MILDE, S., PLOETZ, C., WITTLIEB, J., HEMMRICH, G. and BOSCH, T.C.G. (2007). Transgenic stem cells in Hydra reveal an early origin for key elements controlling self-renewal and differentiation. Dev. Biol. 309: 32-44.

KORTSCHAK, R. D., SAMUEL, G., SAINT, R. and MILLER, D. J. (2004). EST analysis of the cnidarians Acropora millepora reveals extensive gene loss and rapid sequence divergence in the model invertebrates. Curr. Biol. 13:2190-2195.

KROIHER, M. (2000). Morphological chimeras of larvae and adults in a hydrozoan: Insights into the control of pattern formation and morphogenesis. Int. J. Dev. Biol. 44: 861-866.

KROIHER M, PLICKERT G, and MÜLLER WA. (1990). Pattern of cell proliferation in embryogenesis and planula development of Hydractinia echinata predicts the postmetamorphic body pattern. Roux's Arch. Dev. Biol. 199: 156-163.

KUENZEL, T., HEIERMANN, R., FRANK, U., MÜLLER, W.A., TILMANN, W., BAUSE, M., NONN, A., HELLING, M., SCHWARZ, R.S. and PLICKERT, G. (2010). Migration and differentiation potential of stem cells in the cnidarian Hydractinia analysed in eGFP-transgenic animals and chimeras. Dev. Biol. 348 : 120-129.

LANGE, R., DICK, M. and MÜLLER, W.A. (1992). Specificity and early ontogeny of historecognition in the hydroid Hydractinia. J. Exp. Zool. 262: 307-316.

LANGE, R. and MÜLLER, W.A. (1991). SIF, a novel morphogenetic inducer in Hydrozoa. Dev. Biol. 147: 121-132.

LANGE, R., PLICKERT, G. and MÜLLER, W.A. (1989). Histoincompatibility in a low invertebrate, Hydractinia echinata. Analysis of the mechanism of rejection. J. Exp. Zool. 249: 284-292.

LEITZ, T., MORAND, K. and MANN, M. (1994). Metamorphosin A: A novel peptide controlling development of the lower metazoan Hydractinia echinata(Coelenterata, Hydrozoa). Dev. Biol. 163: 440-446.

LINDGENS, D., HOLSTEIN, T.W. and TECHNAU, U. (2004). Hyzic, the Hydra homolog of the zic/odd-paired gene, is involved in the early specification of the sensory nematocytes. Development 131: 191-201.

LITTLEFIELD, C.L. (1985). Germ cells in Hydra oligactis males. 1. Isolation of a subpopulation of interstitial cells that is developmentally restricted to sperm production. Dev. Biol. 112: 185-193.

LITTLEFIELD, C.L. (1991). Cell line lineages in hydra: Isolation and characterization of an interstitial stem cell restricted to egg production in Hydra oligactis. Dev. Biol. 143: 378-388.

MALI, B., MOEHRLEN, F., FROHME, M. and FRANK, U. (2004). A putative double role of a chitinase in a cnidarian: pattern formation and immunity. Dev. Compar. Immunol. 28: 973-981.

MALI, B., SOZA-RIED, J. FROHME, M. and FRANK, U. (2006). Structural but not functional conservation of an immune molecule: a tachylectin-like gene in $\mathrm{Hy}$ dractinia. Dev. Comp. Immunol. 30: 275-281.

MALI, B., MILLANE R.C., PLICKERT, G., FROHME, M. and FRANK, U. (2011). A polymorphic, thrombospondin domain-containing lectin is an oocyte marker in Hydractinia: implications for germ cell specification and sex determination. Int. J. Dev. Biol. 55: 103-108.

MARTIN, V.J. (2000). Reorganization of the nervous system during metamorphosis of a hydrozoan planula. Invertebr. Biol. 119: 243-253.

MARTIN V.J. and ARCHER, W.E. (1986). Migration of interstitial cells and their derivatives in a hydrozoan planula. Dev. Biol. 116: 486-496.

MARTIN V.J. and ARCHER, W.E. (1997). Stages of larval development and stem cell population changes during metamorphosis of a hydrozoan planula. Biol. Bull. 192: 41-52.

MARTINDALE, M.Q. and HEJNOL, A. (2009). Adevelopmental perspective: changes in the position of the blastopore during bilaterian evolution. Dev. Cell 17: 162-174

MASUDA-NAKAGAWA, L.M., GROER, H., AERNE, B.L. and SCHMID, V. (2008). The HOX-like gene Cnox2-PC is expressed at the anterior region in all life cycle stages of the jellyfish Podocoryne carnea. Dev. Genes Evol. 210: 151-6.

MILJKOVIC, M., MAZET, F. and GALLIOT, B. (2002). Cnidarian and bilaterian promoters can direct GFP expression in transfected hydra. Dev. Biol. 246: 377-390.

MILJKOVIC-LICINA, M., CHERA, S., GHILA, L. and GALLIOT, B. (2007). Head regeneration in wild-type hydra requires de novo neurogenesis. Development
134: 1191-1201.

MILLANE, R.C., KANSKA, J., DUFFY, D.J., SEOIGHE, C., CUNNINGHAM, S. PLICKERT, G. and FRANK, U. (2011). Induced stem cell neoplasia in a cnidarian by ectopic expression of a POU domain transcription factor. Development 138: 2429-2439.

MOCHIZUKI, K., NISHIMIYA-FUJISAWA, C. and FUJISAWA, T. (2001). Universal occurrence of the vasa-related genes among metazoans and their germline expression in Hydra. Dev. Genes Evol. 211: 299-308.

MOCHIZUKI, K., SANO, H., KOBAYASHI, S. etal. (2000). Expression and evolutionary conservation of nanos-related genes in Hydra. Dev. Genes Evol. 210: 591-602.

MOKADY, O. and BUSS, L.W. (1996).Transmission genetics of allorecognition in Hydractinia symbiolongicarpus (Cnidaria: Hydrozoa). Genetics 143: 823-827.

MOMOSE, T., DERELLE, R. and HOULISTON, E. (2008). A maternally localised WNT ligand required for axial patterning in the cnidarian Clytia hemisphaerica. Development 135: 2105-2113.

MOMOSE, T. and SCHMID, V. (2006). Animal pole determinants define oral-aboral axis polarity and endodermal cell-fate in hydrozoan jellyfish Podocoryne carnea. Dev. Biol. 292: 371-80.

MÜLLER, W.A. (1964). Experimental investigations on colony development, polyp differentiation and sexual chimeras in Hydractinia echinata (Foreign title: Experimentelle Untersuchungen über Stockentwicklung, Polypendifferenzierung und Sexualchimären bei Hydractinia echinata). Wilhelm Roux' Archiv für Entwicklungsmechanik. 155: 181-268.

MÜLLER, W.A. (1967). Differentiation potentials and sex stability of the i-cells of Hydractinia echinata(Foreign title: Differenzierungspotenzen und Geschlechtsstabilität der I-Zellen von Hydractinia echinata.) Wilhelm Roux' Archiv für Entwick lungsmechanik. 159: 412-432.

MÜLLER, W.A. (1982). Intercalation and pattern regulation in hydroids. Differentiation 22: 141-150.

MÜLLER, W.A. (1984). Retinoids and pattern formation in a hydroid. J. Embryol. Exp. Morphol. 81: 253-271.

MÜLLER, W.A. (1985). Tumor-promoting phorbol esters induce metamorphosis and multiple head formation in the hydroid Hydractinia. Differentiation 29: 216-222.

MÜLLER, W.A. (1996). Defense of conspecific habitat competitors in Hydractinia echinata. Encyclopaedia Cinematographica VHS-Video C 1907. Institut für den Wissenschaftlichen Film, Göttingen.

MÜLLER, W.A. (2002). Autoaggressive, multi-headed and other mutant phenotypes in Hydractinia echinata (Cnidaria: Hydrozoa). Int. J. Dev. Biol. 46: 1023-1033.

MÜLLER, W.A., FRANK, U., TEO, R., MOKADY, O., GUETTE, C. and PLICKERT, G. (2007).Wnt signaling in hydroid development: ectopic heads and giant buds induced by GSK-3 beta inhibitors. Int. J. Dev. Biol. 51: 211-220.

MÜLLER, W.A., HAUCH, A. and PLICKERT, G. (1987). Morphogenetic factors in hydroids. I Stolon tip activation and inhibition. J. Exp. Zool. 243: 111-124.

MÜLLER, W.A. and LEITZ, T. (2002). Metamorphosis in the Cnidaria. Canad. J. Zool. 80: 1755-1771.

MÜLLER, W.A. and PLICKERT, G. (1982). Quantitative analysis of an inhibitory gradient field in the hydrozoan stolon. Roux's Arch. Dev. Biol. 191: 56-63.

MÜLLER, W.A., PLICKERT, G. and BERKING, S. (1986). Regeneration in Hydrozoa: Distal vs proximal transformation in Hydractinia echinata. Roux's Arch. Dev. Biol. 195: 513-518.

MÜLLER, W.A., TEO, R. and FRANK, U. (2004a). Totipotency of migratory stem cells in a hydroid. Dev. Biol. 275: 215-224

MÜLLER, W.A., TEO, R. and MOEHRLEN, F. (2004b). Patterning a multi-headed mutant in Hydractinia: enhancement of head formation and its phenotypic normalization. Int. J. Dev. Biol. 48: 9-15.

MULLER, P., SEIPEL, K., YANZE, N., REBER-MULLER, S., STREITWOLF-ENGEL, R., STIERWALD, M., SPRING, J. and SCHMID, V. (2003). Evolutionary aspects of developmentally regulated helix-loop-helix transcription factors in striated muscle of jellyfish. Dev. Biol. 255: 216-29.

NEUMANN, R. (1979). Bacterial induction of settlement and metamorphosis in the planula larvae of Cassiopea andromeda (Cnidaria: Scyphozoa, Rhizostomeae). Mar. Ecol. 1: 21-28.

NICOTRA, M.L., POWELL, A.E., ROSENGARTEN, R.D., MORENO, M., GRIMWOOD, J., LAKKIS, F.G., DELLAPORTA, S. and BUSS, L.W. (2009). A hypervariable invertebrate allodeterminant. Curr. Biol. 19: 583-589. 
NISHIMAYA-FUJISAWA, C. (2012). Germline stem cells and sex determination in Hydra. Int J Dev Biol 56: 499-508.

NISHIMIYA-FUJISAWA, C. and SUGIYAMA, T. (1993). Genetic analysis of developmental mechanisms in hydra: $X X$. Cloning of interstitial stem cells restricted to the sperm differentiation in pathway in Hydra magnipapillata. Dev. Biol. 157: 1-9.

NISHIMIYA-FUJISAWA, C. and SUGIYAMA, T. (1995). Genetic analysis of developmental mechanisms in hydra. XXII. Two types of female germ stem cells are present in a male strain of Hydra magnipapillata. Dev. Biol. 172: 324-336.

PLICKERT, G., JACOBY, V., FRANK, U.,.MÜLLER, W.A. and MOKADY, O. (2006). Wnt signaling in hydroid development: Formation of the primary body axis and its subsequent patterning. Dev. Biol. 298: 368-378.

PLICKERT, G., HERINGER, A. and HILLER, B. (1986). Analysis of spacing in a periodic pattern. Dev. Biol. 120: 399-411.

PLICKERT, G. and KROIHER, M. (1988). Proliferation kinetics and cell lineages can be studied in whole mounts and macerates by means of BrdU/anti-BrdU technique. Development 103: 791- 794.

PLICKERT, G., KROIHER, M. and MUNCK, A. (1988). Cell proliferation and early differentiation during embryonic development and metamorphosis of Hydractinia echinata. Development 103: 795-803.

PLICKERT, G., SCHETTER, E., VERHEY-VAN-WIJK, N., SCHLOSSHERR, J., STEINBUECHEL, M. and GAJEWSKI, M. (2003). The role of alpha-amidated neuropeptides in hydroid development: LWamides and metamorphosis in $\mathrm{Hy}$ dractinia echinata. Int. J. Dev. Biol. 47: 439-450.

POUDYAL, M., ROSA, S., POWELL, A.E., MORENO, M., DELLAPORTA, S.L., BUSS, L.W. and LAKKIS, F.G. (2007). Embryonic chimerism does not induce tolerance in an invertebrate model organism. Proc. Nat. Acad. Sci. USA 104: 4559-4564

QUIQUAND, M., YANZE, N., SCHMICH, J., SCHMID, V., GALLIOT, B. and PIRAINO, S. (2009). More constraint on ParaHox than Hox gene families in early metazoan evolution. Dev. Biol. 328: 173-187.

REBER-MUELLER, S., STREITWOLF-ENGEL, R., YANZE, N., SCHMID, V., STIERWALD, M., ERB, M. and SEIPEL, K. (2006). BMP2/4 and BMP5-8 in jellyfish development and transdifferentiation. Int. J. Dev. Biol. 50: 377-384.

REBSCHER, N., VOLK, C., TEO, R. and PLICKERT, G. (2008). The germ plasm component Vasa allows tracing of the interstitial stem cells in the cnidarian Hydractinia echinata. Dev. Dyn. 237: 1736-45.

ROSA, S.F.P., POWELL, A.E., ROSENGARTEN, R.D., NICOTRA, M.L., MORENO, M.A., GRIMWOOD, J., LAKKIS, F.G., DELLAPORTA, S. and BUSS, L.W. (2010). Hydractinia allodeterminant alr1 resides in an immunoglobulin superfamily-like gene complex. Curr. Biol. 20: 1122-1127.

ROSENGARTEN, R.D., MORENO, M.A., LAKKIS, F.G., BUSS, L.W. and DELLAPORTA, S.L. (2011a). Genetic diversity of the allodeterminant alr2 in Hydractinia symbiolongicarpus. Molec. Biol. Evol. 28: 933-47.

ROSENGARTEN, R.D. and NICOTRA, M.L. (2011). Model systems of allorecognition. Curr. Biol. 21: R82-R92.

SACKS, P.G. and DAVIS, L.E. (1979). Production of nerveless Hydra attenuata by hydroxyurea treatments. J. Cell Sci. 37: 189- 203.

SCHMICH, J., TREPEL, S. and LEITZ, T. (1998). The role of GLWamides in metamorphosis of Hydractinia echinata. Dev. Genes Evol. 208: 267-273.

SCHMID, V. (1992). Transdifferentiation in medusae. In: JEON, K.W. and FRIEDLANDER, M. (eds). Int. Rev. Cytol.142: 213-261.

SCHMID, V., BAADER, C., BUCCIARELLI, A. et al. (1993). Mechanochemical interactions between striated muscle cells of jellyfish and grafted extracellular matrix can induce and inhibit DNA replication and transdifferentiation in vitro. Dev. Biol. 155: 483-496.

SCHMID V and PLICKERT G. (1990). The proportion altering factor (PAF) and the in vitro transdifferentiation of isolated striated muscle of jellyfish into nerve cells. Differentiation 44: 95-102

SCHMID, V. and REBER-MUELLER, S. (1995). Transdifferentiation of isolated striated muscle of jellyfish in vitro: the initiation process. Sem. Cell Biol. 6: 109-116.

SCHMID, V., WYDLER, M. and ALDER, H. (1982). Transdifferentiation and regeneration in vitro. Dev. Biol. 92: 476-488.

SCHWARZ, R.S., HODES-VILLAMAR, L., FITZPATRICK, K.A., FAIN, M.G., HUGHES, A.L. and CADAVID, L.F. (2007). A gene family of putative immune recognition molecules in the hydroid Hydractinia. Immunogenetics. 59: 233-46.

SCHWOERER-BÖHNING, B., KROIHER, M. and MÜLLER, W.A. (1990). Signal transmission and covert prepattern in the metamorphosis of Hydractinia echinata (Hydrozoa).Roux's Arch. Dev. Biol. 198: 245-251.

SCHUCHERT, P. (2011). Podocoryne carnea M. Sars, 1846. In: Schuchert, P. World Hydrozoa database. World Register of Marine Species. www.marinespecies.org/ aphia. php? $\mathrm{p}=$ taxdetails\&id $=220573$

SCHUCHERT, P. (2012). The Hydrozoa Directory. (www.ville-ge.ch/mhng/hydrozoa/ hydrozoa-directory.htm).

SEIPEL, K., EBERHARDT, M., MULLER, P., PESCIA, E., YANZE, N. and SCHMID, V. (2004a). Homologs of vascular endothelial growth factor and receptor, VEGF and VEGFR, in the jellyfish Podocoryne carnea. Dev. Dyn. 231: 303-12.

SEIPEL, K. and SCHMID, V. (2005). Evolution of striated muscle: Jellyfish and the origin of triploblasty. Dev. Biol. 282: 14-26.

SEIPEL, K. and SCHMID V. (2006). Mesodermal anatomies in cnidarian polyps and medusae. Int. J. Dev. Biol. 50: 589-599.

SEIPEL, K., YANZE, N. and SCHMID, V. (2004b). The germ line and somatic stem cell gene Cniwi in the jellyfish Podocoryne carnea. Int. J. Dev. Biol. 48: 1-7.

SEIPP, S., SCHMICH, J. and LEITZ, T. (2001). Apoptosis:Adeath-inducing mechanism tightly linked with morphogenesis in Hydractinia echinata (Cnidaria, Hydrozoa). Development. 128: 4891-4898.

SEIPP, S., SCHMICH, J., WILL, B., SCHETTER, E., PLICKERT, G. and LEITZ T. (2010). Neuronal cell death during metamorphosis of Hydractina echinata (Cnidaria, Hydrozoa). Invertebr. Neurosci. 10: 77-91.

SHIMIZU, H. (2012). Transplantation analysis of developmental mechanisms in Hydra. Int J Dev Biol 56: 463-472.

SIEBERT, S., ANTON-ERXLEBEN, F. and BOSCH, T.C.G. (2008). Cell type complexity in the basal metazoan Hydra is maintained by both by stem cell based mechanisms and transdifferentiation. Dev. Biol. 313: 13-24.

SOZA-RIED, J., HOTZ-WAGENBLATT, A., GLATTING, K-H., DEL VAL, C., FELLENBERG, K., BODE, H.R., FRANK, U., HOHEISEL, J.D. and FROHME, M. (2010). The transcriptome of the colonial marine hydroid Hydractinia echinata. FEBS J. 277: 197-209.

SPRING, J., YANZE, N., JOSCH, C., MIDDEL, A.M., WINNINGER, B., and SCHMID, V. (2002). Conservation of Brachyury, Mef2, and Snail in the myogenic lineage of jellyfish: a connection to the mesoderm of bilateria. Dev. Biol. 244: 372-84.

SPRING, J., YANZE, N., MIDDEL, A.M., STIERWALD, M., GROGER, H. and SCHMID, V. (2000). The mesoderm specification factor twist in the life cycle of jellyfish. Dev. Biol. 228: 363-75.

STEELE, R.E. (2012). The Hydra genome: insights, puzzles, and opportunities for developmental biologists. Int J Dev Biol 56: 535-542.

STIERWALD, M., YANZE, N., BAMERT, R.P., KAMMERMEIER, L. and SCHMID, V. (2004). The Sine oculis/Six class family of homeobox genes in jellyfish with and without eyes: development and eye regeneration. Dev. Biol. 274: 70-81.

STUMPF, M., WILL, B., WITTIG, K., KASPER, J., FISCHER, B., SCHMICH, J., SEIPP, S. and LEITZ, T. (2010). An organizing region in metamorphosing hydrozoan planula larvae - stimulation of axis formation in both larval and in adult tissue. Int. J. Dev. Biol. 54: 795-802.

SUGIYAMA, T. and FUJISAWA, T. (1979). Genetic analysis of developmental mechanisms in the hydra. Part 6. Cellular composition of chimera hydra. J. Cell Sci. 35: 1-16.

TARDENT, P. (1978). Coelenterata. Cnidaria. Jena Gustav Fischer Verlag.

TEBBEN, J.; TAPIOLAS, D.M., MOTTI, C.A., NEGRI, D., ANDREW, P., BLACKALL, L.L., STEINBERG, P.D. and HARDER, T. (2011). Induction of larval metamorphosis of the coral Acropora millepora by tetrabromopyrrole isolated from a Pseudoalteromonas bacterium. PLoS One 6: e19082.

TECHNAU, U. and STEELE, R.E. (2011). Evolutionary crossroads in developmental biology: Cnidaria. Development 138: 1447-1458.

TEO, R., FRANK, M., PLICKERT, G., MÜLLER, W.A. and FRANK, U. (2006). An evolutionary conserved role of Wnt signaling in stem cell fate decision. Dev. Biol. 289: 91-99.

TERAGAWA, C.K. and BODE, H.R. (1990) Spatial and temporal patterns of interstitial cell migration in Hydra vulgaris. Dev. Biol. 138: 63-81

TORRAS, R. and GONZALEZ-CRESPO, S. (2005). Posterior expression of nanos orthologs during embryonic and larval development of the anthozoan Nematostella vectensis. Int. J. Dev. Biol. 49: 895-9.

TORRAS, R., YANZE, N., SCHMID, V. and GONZALEZ-CRESPO S. (2004). nanos 


\section{G. Plickert et al.}

expression at the embryonic posterior pole and the medusa phase in the hydrozoan Podocoryne carnea. Evol. \& Dev. 6: 362-71.

VAN DE VYVER, G. (1964). Histological studies on development of Hydractinia echinata. (Foreign title: Etude histologique du development d'Hydractinia echinata (Flem.) Cahiers de Biologie Marine, Tome V: 295-310.

WATANABE, H., HOANG, V.T., MAETTNER, R. and HOLSTEIN, T. (2009). Immortality and the base of multicellular life: Lessons from cnidarian stem cells. Semin. Cell \& Dev. Biol. 20: 1114-1125.

WEIS, V.M. and BUSS, L.W. (1987). Ultrastructure of metamorphosis in Hydractinia echinata. Postilla 199: 1-20.

WEISMANN, A. (1883). The origin of the sexual cells in hydromedusae (Foreign title: Die Entstehung der Sexualzellen bei Hydromedusen), Jena, Gustav Fischer
WEISMANN, A. (1889). Essays upon heredity, Oxford Clarendon Press.

WEISMANN, A. (1893). Germ plasm, a theory of heredity. Charles Scribner's Sons

WITTLIEB, J., KHALTURIN, K., LOHMANN, J.U., ANTON-ERXLEBEN, F. and BOSCH, T.C.G. (2006). Transgenic Hydra allow in vivo tracking of individual stem cells during morphogenesis. Proc. Nat. Acad. Sci. USA 103: 6208-6211.

YANZE, N., GROGER, H., MULLER, P. and SCHMID, V. (1999). Reversible inactivation of cell-type-specific regulatory and structural genes in migrating isolated striated muscle cells of jellyfish. Dev. Biol. 213: 194-201.

YANZE, N., SPRING, J., SCHMIDLI, C. and SCHMID, V. (2001). Conservation of Hox/ParaHox-related genes in the early development of a cnidarian. Dev. Biol. 236: 89-98. 


\section{Further Related Reading, published previously in the Int. J. Dev. Biol.}

A polymorphic, thrombospondin domain-containing lectin is an oocyte marker in Hydractinia: implications for germ cell specification and sex determination

Brahim Mali, R. Cathriona Millane, Günter Plickert, Marcus Frohme and Uri Frank

Int. J. Dev. Biol. (2011) 55: 103-108

An organizing region in metamorphosing hydrozoan planula larvae - stimulation of axis formation in both larval and in adult tissue Melanie Stumpf, Britta Will, Karola Wittig, Jennifer Kasper, Benjamin Fischer, Jürgen Schmich,

Stefanie Seipp and Thomas Leitz

Int. J. Dev. Biol. (2010) 54: 795-802

Wnt signaling in hydroid development: ectopic heads and giant buds induced by GSK3beta inhibitors

Werner Müller, Uri Frank, Regina Teo, Ofer Mokady, Christina Guette and Günter Plickert Int. J. Dev. Biol. (2007) 51: 211-220

The role of alpha-amidated neuropeptides in hydroid development--LWamides and metamorphosis in Hydractinia echinata

Günter Plickert, Eva Schetter, Nicole Verhey-Van-Wijk, Jörg Schlossherr, Marlis Steinbüchel and Martin Gajewski

Int. J. Dev. Biol. (2003) 47: 439-450

Autoaggressive, multi-headed and other mutant phenotypes in Hydractinia echinata (Cnidaria: Hydrozoa)

Werner A Müller

Int. J. Dev. Biol. (2002) 46: 1023-1033

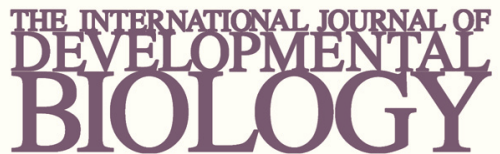

Volume 54 Nos. $6 / 7$
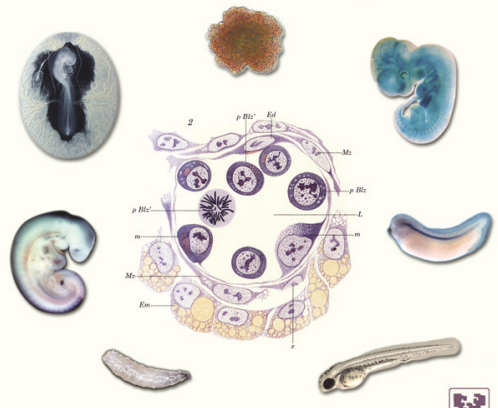

Developmental Hematopoiesis
5 yr ISI Impact Factor $(2010)=2.961$

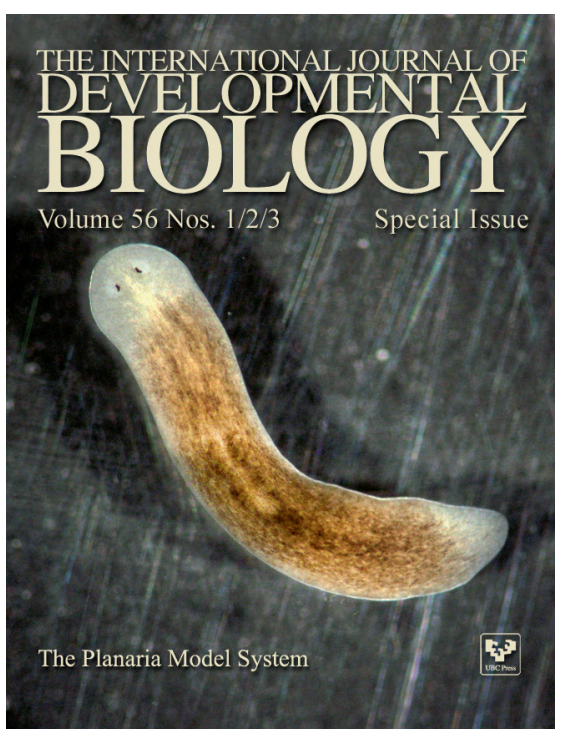

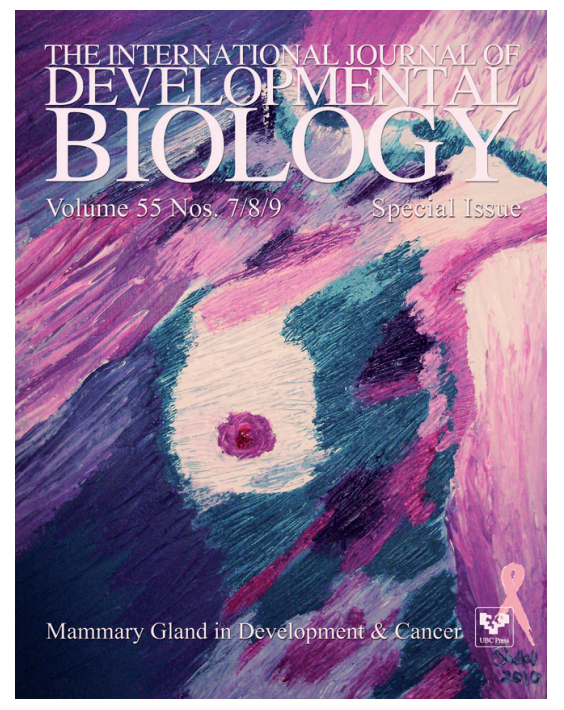

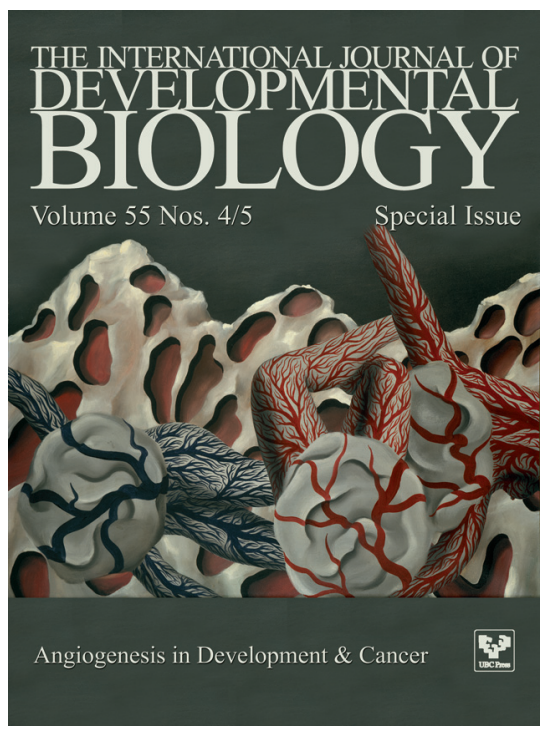

